\title{
WEB
}

WISSENSCHAFTSZENTRUM BERLIN FÜR SOZIALFORSCHUNG

SOCIAL SCIENCE RESEARCH

CENTER BERLIN

Kai A. Konrad *

Salmai Qari **

\section{The Last Refuge of a Scoundrel? \\ Patriotism and Tax Compliance}

* WZB, Free University of Berlin and Max Planck Institute for Intellectual Property, Competition and Tax Law

** WZB

SP || $2009-04$

March 2009

ISSN Nr. $0722-6748$

Research Area

Markets and Politics

Research Unit

Market Processes and Governance
Schwerpunkt

Märkte und Politik

Abteilung

Marktprozesse und Steuerung 
Zitierweise/Citation:

Kai A. Konrad, Salmai Qari, The Last Refuge of a Scoundrel?

Patriotism and Tax Compliance, Discussion Paper SP II 2009 - 04, Wissenschaftszentrum Berlin, 2009.

Wissenschaftszentrum Berlin für Sozialforschung gGmbH,

Reichpietschufer 50, 10785 Berlin, Germany, Tel. (030) 25491 - 0

Internet: www.wzb.eu 


\title{
The Last Refuge of a Scoundrel? Patriotism and Tax Compliance
}

\author{
by Kai A. Konrad and Salmai Qari *
}

We study the effects of patriotism on tax compliance. In particular, we assume that individuals feel a (random draw of) warm glow from honestly paying their taxes. A higher expected warm glow reduces the government's optimal audit probability and yields higher tax compliance. Second, individuals with higher warm glow are less likely to evade taxes. This prediction is confirmed empirically by a multivariate analysis on the individual level while controlling for several other potentially confounding factors. The findings survive a variety of robustness checks, including an instrumental variables estimation to tackle the possible endogeneity of patriotism. On the aggregate level, we provide evidence for a negative correlation between average patriotic warm glow and the size of the shadow economy across several countries.

Keywords: Patriotism, tax evasion, warm glow

JEL Classification: H26, K42

\section{ZUSAMMENFASSUNG}

\section{Die letzte Zuflucht eines Schurken? Patriotismus und Steuerehrlichkeit}

Ob ein Individuum versucht, durch falsche Angaben gegenüber den Steuerbehörden die persönliche Steuerlast zu reduzieren, hängt sowohl von "monetären" als auch von nicht-monetären Faktoren ab. Monetäre Faktoren sind vor allem die Wahrscheinlichkeit, mit der ein versuchter Betrug aufgedeckt wird, und die Höhe der Strafzahlung. Wir untersuchen zunächst theoretisch, wie Patriotismus (Heimatbindung) als ein nicht-monetärer Faktor die Steuerehrlichkeit beeinflusst. Personen mit gleichem Einkommen, aber höherer Heimatbindung, geben auch mit höherer Wahrscheinlichkeit ihr Einkommen korrekt an. Weiterhin führt eine Erhöhung der durchschnittlichen Heimatbindung über die gesamte Steuerbevölkerung dazu, dass im Gleichgewicht der Anteil der Steuerhinterzieher geringer wird. Diese beiden Hypothesen werden empirisch mit Hilfe von Surveydaten überprüft und bestätigt. Für die erste Hypothese auf Ebene des Individuums erlauben es die Daten, die Robustheit des empirischen

\footnotetext{
We thank Tom Cusack and Benny Geys for generous comments and suggestions. We are also grateful to seminar participants at WZB Berlin and Ifo Institute for Economic Research, Dresden for helpful comments. The usual caveat applies. Konrad gratefully acknowledges financial support provided by the Deutsche Forschungsgemeinschaft and the Agence Nationale de la Recherche in the project “Competition among Nation States”. Qari gratefully acknowledges support from the Anglo-German foundation through the CSGE research initiative.
} 
Ergebnisses umfangreich zu überprüfen. Eine Vielzahl von Spezifikationen, inklusive einer Instrumentvariablenschätzung, bestätigen den positiven Zusammenhang zwischen Heimatbindung und (der Einstellung zur) Steuerehrlichkeit. 


\section{Introduction}

Patriotism plays a role for public finance. Especially in times of war, politicians appeal strongly to patriotism and to citizens' national pride trying to increase their tax compliance or to implement tax reform. As documented by Jones (1996), the US Treasury used mass media such as radio, magazines and movies, and hired professional advertisers, entertainers and movie directors during World War II. Even Walt Disney was hired by the US Secretary of the Treasury, Henry Morgenthau Jr., to produce the movie The New Spirit, with Donald Duck staring as the average citizen. Donald Duck learns on the radio that it is his privilege as a citizen to make his tax contributions. Reluctant first and afraid of the intricate aspects of tax filing, he then finds out that tax filing is easy and his resulting tax burden very small. Patriotic feelings are instrumental for convincing Donald that his taxes serve a good purpose: pay taxes to beat the Axis. ${ }^{1}$ Tax compliance, hence, gives him a patriotic warm glow. Jones (1996, p. 126) reports that this movie had been seen by over 32 million people, and, according to a Gallup poll, affected the willingness to pay taxes of 37 percent of the viewers.

The role of patriotism for the government's ability to tax has already been recognized by Hill (1894, p. 451) who studied war finance during the civil war. He argued:

An income tax has the considerable advantage of being responsive to the influences of patriotism, which are certain to be strong whenever a serious war is undertaken by a democratic country. [...] But the productiveness of an income tax depends, in large measures, upon the readiness of men to reveal their incomes and meet the tax. To this extent it assumes the nature of a voluntary contribution, to which men will respond more freely when they realize that the hour is one of the sore need and perhaps, of peril to the country.

Related to this, there is an old discussion about the role of patriotism during war for implementing long-lasting tax reforms. Adams (1911, p. 318) discusses the role of patriotism for overcoming the deadlock of tax reform that emerges from the rivalry of interest groups. More recently, Bank, Stark and Thorndike (2008) analyze the instrumental role of wars and the patriotism generated by such events for tax reform. Their key argument is that wars may cause feelings of solidarity and shared sacrifice, and this may create a window of opportunity for revenue increasing tax reform. Levi (1997) develops a theory of compliance based on contingent consent. Feldman and Slemrod (2006) discuss the possible role of propaganda for generating a mentality of solidarity and for overcoming free riding incentives.

These studies focus on the increase in patriotism during war, compared to a lower level of patriotism during peace, and the instrumental role that this higher patriotism

\footnotetext{
${ }^{1}$ See also Jones (1989: 716n) and Watts (1995: 103n.).
} 
may play for tax policy and tax reform. ${ }^{2}$ We consider the role of patriotism for tax compliance and for tax evasion toward the shadow economy in times of peace. We analyze the role of patriotic feelings and its distribution among the population within a country for the country's optimal tax auditing policy. We expect that an individual's patriotism and the auditing policy should jointly influence the individual's compliance decision.

More formally, we follow Hill's (1894) suggestion quoted above about the instrumental role of patriotism: honest tax compliance is -to a certain degree- a matter of choice. The payment of taxes, hence, has features of a voluntary contribution to a common good. We take note of the effect that "individuals are far more compliant than our theory might predict." (Andreoni, Erard and Feinstein 1998, p. 850). One possible explanation for this has been put forward in the context of "tax morale": individuals may have good feelings about fulfilling their tax obligations or may feel a "warm glow of giving" when making their financial contribution to the government budget. ${ }^{3}$ More specifically, we assume that tax payments generate a patriotic "warm glow", and a higher warm glow for more patriotic persons. We then analyze the theoretical and empirical implications of such a patriotic warm glow. On the country level we find that a higher expected patriotic warm glow implies that the optimal tax auditing probability is lower, while at the same time tax compliance is increased. On the individual level we show that persons who happen to receive a larger draw from the distribution of warm glow, are less likely to evade their taxes. These are our main hypotheses which we confront with the data. Our main data sources are two modules of the International Social Survey Programme (ISSP) on "National Identity", from which we derive measures of patriotism. On the country level we use the size of the shadow economy as a proxy for tax evasion and show a negative correlation between tax evasion and patriotism. We then move to the individual level and use only those respondents' observations who also have participated in the ISSP "Citizenship" module. This allows us to link an individual's patriotic sentiments to this person's attitude toward tax evasion. While controlling for several other potentially confounding factors, we show that patriotism has a large positive effect on tax compliance. ${ }^{4}$

\footnotetext{
${ }^{2}$ A more indirect reasoning uses essentially the same rationale: Anderson (1917) suggests financing war by taxes rather than by debt. He argues that the increased patriotism during wartime makes tax payment during wartime more feasible, whereas debt needs to be financed by taxes once the war has ended. In a similar vein, Durand (1917, p.902) explains: "The patriotism which during the war itself might induce the rich willingly to pay taxes according to the full measure of their ability is bound to wane considerably when the war is over."

${ }^{3}$ The term "warm glow" has been coined by Andreoni $(1989,1990)$ in the context of voluntary contributions to a public good. It also receives empirical support: Harbaugh et al. (2007) find evidence from brain scans suggesting that tax payments in experiments may cause physiological rewards. Crumpler and Grossman (2008) perform experiments to test warm glow giving. Although the participants know that every dollar they contribute will be fully crowded out, roughly $57 \%$ of the persons make a donation.

${ }^{4}$ Slemrod (2007) discusses the possibility of a relationship between tax compliance and patriotism. He also surveys the experimental works by Blumenthal, Christian and Slemrod (2001) and Torgler
} 
Patriotism is not necessarily the most important reason for why tax compliance is so high or -paraphrasing Andreoni, Erard and Feinstein (1998, p. 821)- why there are so many honest households and why cheaters do not cheat by more. Many other issues relating to social norms and psychology have been suggested and been shown to be empirically relevant. ${ }^{5}$ However, the evidence documented by Jones (1996) shows that governments have appealed consciously to patriotism and instrumentalized its existence, and the quantitative effect of patriotism is substantial.

We think that the study of the role of patriotism in the context of collecting revenue is particularly important for another reason: patriotism itself is potentially the result of governmental policy, leading to normative questions regarding patriotism. Indeed, anecdotal evidence from many countries suggests that governments are engaged in instilling patriotism, using their regulatory influence on the education system. ${ }^{6}$ The logic behind this behavior is similar to that of firms which invest in building up customer relations and later exploit their bases of loyal customers when charging higher prices. In parallel to this logic, the government may instill patriotic preferences in its citizens, planning to draw on these loyalties for various purposes, including military draft, the collection of fiscal revenues and other voluntary activities or things that 'citizens can do for their country'. The effect of patriotism on tax compliance makes more patriotism a desirable aim for a revenue-oriented government. What may cause uneasiness with this compelling logic is the fact that patriotism may have a number of highly undesirable side effects, particularly if it turns into nationalism.

We proceed as follows. In section 2 we outline the mechanism by which higher patriotism in a population causes a reduction of the optimal tax auditing intensity and an increase in tax compliance. This yields our main hypothesis which we test in the empirical part of the paper. This part is divided into four sections and starts with a description of the data. We confirm our theoretical predictions on the country level in section 4 and provide the results for the individual level in section 5. After discussing

(2004b). They both refute any significantly positive relationship between moral suasion and tax compliance in these experiments. This contrasts interestingly with our empirical evidence.

${ }^{5}$ These include intrinsic motivation potentially being crowed out by extrinsic incentives (Frey 1997), mental suffering from evading taxes (Gordon 1989, Coricelli, Joffily, Montmarquette and Villeval 2007), tax morale, moral sentiments, and an inclination for pro-social behavior (see Frey and Torgler 2007 for a survey), fairness considerations (Hartner et al. 2008), religiosity (Torgler 2006) and cultural background (Torgler and Schneider 2007). See also the surveys by Andreoni, Erard and Feinstein (1998) and Slemrod (2007).

${ }^{6}$ There are many examples, across different times and political regimes. Maosen (1990) describes that instilling patriotism was an important aspect of education policy in imperial, Maoist and more recent China. The Economist (19/12/06, page 92) reports about legislation in Japan that requires schools to instill "a love of one's country" in children. The East German government prior to 1989 made "loving the German Democratic Republic" the first law for their (essentially mandatory) youth organizations. The government in Poland discussed about introducing patriotism as an independent subject in 2006 (Neue Züricher Zeitung, 11/6/2006). In the United States, education theorist Sigal Ben-Porath (2007) seriously argues that patriotism is a virtue that should be taught at school, and youth organizations such as the Boy Scouts subscribe in their charter (chapter 3) "...to teach them patriotism, courage, self-reliance and kindred virtues, using the methods which are now in common use by Boy Scouts". 
some robustness checks (section 6) we conclude in section 7 .

\section{The analytics of patriotism}

To illustrate the relationship between patriotism, auditing and tax compliance and to derive our main hypothesis, we consider a simple tax compliance game between a representative citizen or tax payer and a welfare maximizing government. ${ }^{7}$

The citizen has two possible levels of income. Income is equal to $y=1$ with probability $\pi$, and equal to $y=0$ with the remaining probability $1-\pi$. The citizen also has patriotic feelings toward her mother country. This patriotic predisposition is described by the parameter $\eta=h+\epsilon$. It consists of a deterministic component $h$, plus noise $\epsilon$ that is uniformly distributed on the interval $[-a, a]$. Moreover, $y$ and $\epsilon$ are assumed to be stochastically independent. Income $y$ and patriotism $\eta$ jointly determine the citizen's type as a draw from the two-dimensional type space $\{0,1\} \times[h-a, h+a]$. We assume that the citizen knows her type, whereas the government only knows the distribution of types.

Consider the government. We focus on the auditing problem for a given statutory tax rate $t \in[0,1]{ }^{8}$ The government asks the citizen to make a declaration of her taxable income and announces the audit probabilities $\left(q_{\delta=0}, q_{\delta=1}\right) \in[0,1] \times[0,1]$ as a function of the declared income $\delta$. If the audit confirms the declared income, then the government has to charge the statutory tax rate on this income. If the audit reveals a different income then a penal tax rate $\theta \in[0,1]$ applies, which is also chosen by the government and announced to the citizen prior to her declaration.

More formally, the timing and the sets of actions for the citizen and the government are as follows.

At STAGE 1 , for a given statutory tax rate $t \in[0,1]$ the government chooses an auditing technology and commits to this technology. This technology is characterized by the message space $D=\{0,1\}$, auditing probabilities $\left(q_{\delta=0}, q_{\delta=1}\right) \in[0,1] \times[0,1]$ as functions of the message $\delta \in D$, and a penal tax rate $\theta \in[0,1]$ that applies if an audit occurs and $\delta \neq y .^{9}$

\footnotetext{
${ }^{7}$ The seminal tax compliance analysis is by Allingham and Sandmo (1972). Many contributions consider optimal tax enforcement in the context of optimal taxation (Cremer, Marchand and Pestieau 1990, Boadway and Sato 2000). The work closest to our theoretical analysis considers tax auditing with commitment from a contract theory point of view (see, e.g., Reinganum and Wilde 1985, Chander and Wilde 1998 and Macho-Stadler and Perez-Castrillo 1997). The specific feature of our formal framework is the heterogeneity of tax payers along a dimension other than income: patriotic warm glow.

${ }^{8}$ This tax rate could be endogenous in an optimal taxation problem with tax evasion and auditing. However, we focus here on the relationship between tax compliance and patriotism. For this reason we keep the framework as simple as possible.

${ }^{9}$ Note that we restrict the message space to $D=\{0,1\}$, although there is a two-dimensional set of types. Essentially this assumes that the government is not allowed to discriminate between tax payers who differ only in their patriotism. This restriction simplifies the analysis, but it is also plausible. A tax burden that depends on articulated patriotism may violate constitutional principles of horizontal
} 
At STAGE 2 the citizen knows her true income $y \in\{0,1\}$, her patriotism $\eta \in$ $[-a+h, h+a]$ and the auditing policy chosen by the government and chooses a report $\delta \in\{0,1\}$.

At STAGE 3 the government audits the citizen according to the report-dependent probabilities chosen in stage 1 and the actual report in stage 2. Whether or not the government actually audits the citizen is denoted by the indicator variable $\chi \in\{1,0\}$. Taxes or penal taxes are paid according to $y, \delta, \chi, t$ and $\theta$.

The resulting payoffs are as follows. The citizen and the government are risk neutral. The citizen's income is a function of gross income obtained, the reported income, tax payment or potential penal tax as a result of an audit. The net income is 0 if $y=0$. The net income is $1-t$ if $y=1$ and the citizen reports truthfully. The net income is 1 if the citizen's true income is $y=1$, she reports $\delta=0$ and is not audited $(\chi=0)$. The net income is $1-\theta$ if $y=1$ and the citizen reports $\delta=0$ and is audited $(\chi=1)$. Moreover, the citizen has an intrinsic (positive or negative) benefit from voluntarily paying taxes. As discussed in the introduction, this intrinsic benefit may stem from the feeling that she contributes something for her beloved mother country (like Donald in The New Spirit). More specifically, the citizen feels a patriotic warm glow of giving if she reports $\delta=1$ and pays $t$. This warm glow is individual specific and equal to $\eta t .{ }^{10}$ Recall that $\eta=h+\epsilon$ is assumed to be a random variable with mean $h$ and uniform distribution on the interval $[h-a, h+a]$ for a given $a>0$. The citizen feels this warm glow only with taxes paid voluntarily, not with the penalty taxes resulting from being caught for misreporting. ${ }^{11}$ Summarizing, the citizen's payoffs from outcomes $(y, \delta, \chi)$ are

$$
\begin{array}{ccccc}
0 & \text { if } & (y, \delta, \chi) & \in & \{(0,0,0),(0,0,1)\} \\
1 & \text { if }(y, \delta, \chi)= & (1,0,0) \\
1-t+\eta t & \text { if } & (y, \delta, \chi) & \in & \{(1,1,0),(1,1,1)\} \\
1-\theta & \text { if } & (y, \delta, \chi) & = & (1,0,1)
\end{array}
$$

Turn now to the preferences of the government. We assume that the government is fully benevolent and maximizes a weighed sum of the citizen's payoff (including her warm glow) and of tax revenue net of auditing costs. The weight on the government's tax revenue is $(1+\lambda)$ with $\lambda>0$. This takes account of the fact that the shadow value of public funds is, typically, larger than unity. Further, we assume that an audit costs a fixed amount equal to $m>0$. This yields the following payoffs for the government as a

equity. Also empirically, tax payers do declare only their taxable income.

${ }^{10}$ This is a particular simple way to ensure that the warm glow increases in the fraction of income paid as taxes.

${ }^{11}$ This assumption can be relaxed, but it seems natural that the warm glow of giving is larger if the giving occurs voluntarily. A closely related idea is the non-monetary pay-off in the context of social interactions; here the pay-off is usually larger for individuals who behave according to their reference group (eg. Fortin et al., 2007; Brock and Durlauf, 2001). 
function of the possible outcomes $(y, \delta, \chi)$ :

$$
\begin{array}{ccc}
0 & \text { if } \quad(y, \delta, \chi)=(0,0,0) \\
-m & \text { if } \quad(y, \delta, \chi)=(0,0,1) \\
1 & \text { if } \quad(y, \delta, \chi)=(1,0,0) \\
1-m+\lambda \theta & \text { if } \quad(y, \delta, \chi)=(1,0,1) \\
1-t+\eta t+(1+\lambda) t & \text { if } \quad(y, \delta, \chi)=(1,1,0) \\
1-t+\eta t+(1+\lambda) t-m & \text { if } \quad(y, \delta, \chi)=(1,1,1)
\end{array}
$$

We first consider citizen's choices for different tax and auditing policies. From the first line in (1), a citizen with $y=\delta=0$ is indifferent whether she is audited or not. Moreover, it is not feasible for a citizen with $y=0$ to report $\delta=1$, as this citizen cannot pay the taxes that are implied. Hence, we may conclude that citizens with $y=0$ report truthfully $\delta=0$ for all possible audit policies. Consider a citizen with $y=1$. If the citizen reports $\delta=1$ she may be audited with probability $q_{\delta=1}$. She pays a tax $t$ independently of whether she is audited or not. As auditing is costly, $q_{\delta=1}=0$ will hold for the optimal audit policy (as will be seen more formally later). If the citizen reports $\delta=0$, she is audited with probability $q_{\delta=0}$, and, as this is the key choice variable in what follows, we use the short-hand notation $q_{\delta=0} \equiv q$. If no audit takes place, the citizen pays zero taxes. If an audit takes place, the government learns that $y=1$, and the citizen pays a $\operatorname{tax} \theta$. The citizen reports $\delta=1$ rather than $\delta=0$ if

$$
1-t+\eta t \geq 1-q \theta
$$

where we assume that a citizen who is indifferent reports truthfully. Solving this condition for $\eta$ reveals a critical level of patriotism:

$$
\eta_{0}(q \theta)=1-\frac{q \theta}{t}
$$

A citizen reports truthfully iff $\eta \geq \eta_{0}(q \theta)$. Note at this point that the behavior of the citizen is a function of $(q \theta)$ only, and that any $(q, \theta)$ has the same behavioral and payoff implications for the citizen as $(q \theta, 1)$, i.e., an audit that takes place with probability $q \theta$ and has a penal tax rate equal to 1 . This reduces the optimal auditing problem:

Proposition 1 For the optimal auditing policy of the tax compliance game it holds that $q_{\delta=1}=0$ and $\theta=1$.

The formal proof of Proposition 1 is in the supplementary appendix. The result $q_{\delta=1}=0$ has already been discussed. The result $\theta=1$ reproduces the well-known observation (Becker 1968) that a maximum punishment is optimal if auditing is costly and reduces the optimal audit problem to the one-dimensional problem. Hence, the objective of the government reduces to choosing the audit probability $q \in[0,1]$ for $\delta=0$ that maximizes

$$
\begin{aligned}
W(q) \equiv & -(1-\pi) q m \\
& +\pi P(q)\left(1+\lambda t+E\left(\eta \mid \eta \geq 1-\frac{q}{t}\right) t\right) \\
& +\pi(1-P(q))(q(1-m+\lambda)+(1-q))
\end{aligned}
$$


with

$$
P(q) \equiv\left\{\begin{array}{ccc}
1 & \text { if } & q>(1-h+a) t \\
\left.h+a-\left(1-\frac{q}{t}\right)\right) \frac{1}{2 a} & \text { if } & q \in[(1-h-a) t,(1-h+a) t] \\
0 & \text { if } & q<(1-h-a) t
\end{array}\right.
$$

The first term in (4) describes the auditing cost $m$ that occurs with a probability $q$ if the citizen has no income and truthfully reports this zero income. All other terms relate to states in which the citizen has high income $y=1$. As this happens with probability $\pi$, this explains the factor $\pi$ in both these terms. If $\eta_{0}(q) \leq h-a$, then all types of citizens with $y=1$ report truthfully $(P(q)=1)$ and the expected warm glow is $E \eta=h$. Hence,

$$
W(q)=-(1-\pi) q m+\pi(1+\lambda t+h t) .
$$

If $\eta_{0}(q) \geq h+a$, then all citizens with $y=1$ report $\delta=0$. Hence, $(1-P(q))=1$ and

$$
W(q)=-(1-\pi) q m+\pi(1+q(\lambda-m)) .
$$

The third case is obtained if $q$ induces a share $\frac{1}{2 a}\left(h+a-\left(1-\frac{q}{t}\right)\right) \in(0,1)$ of citizen types with $y=1$ to report truthfully, and the remaining share to report $\delta=0$. This yields

$$
\begin{aligned}
W(q)= & -(1-\pi) q m \\
& +\pi \frac{\left.h+a-\left(1-\frac{q}{t}\right)\right)}{2 a}\left(1+\lambda t+\left(1-\frac{q}{t}+h+a\right) \frac{t}{2}\right) \\
& +\pi\left(1-\frac{h+a-\left(1-\frac{q}{t}\right)}{2 a}\right)(q(1-m+\lambda)+(1-q)) .
\end{aligned}
$$

In the second term, $\left(1-\frac{q}{t}+h+a\right) \frac{t}{2}$ is the expected warm glow conditional on $\eta>$ $\eta_{0}(q)$. The last term in (8) is the contribution to welfare if $y=1$ and if $\eta$ is too low to make the citizen report truthfully. In this case the citizen is audited with a probability $q$, leading to welfare $1-m+\lambda$, and not audited with a probability $(1-q)$, leading to welfare equal to the net private income $y=1$.

Note that $W(q)$ in (6) is strictly decreasing in $q$ and $W(q)$ in (7) is monotonically increasing in $q$ for $\pi \lambda>m$. Further, $\pi \lambda>m$ is sufficient to show that $\frac{\partial W(q)}{\partial q}>0$ at $q=(1-h-a) t$, and $W(q)$ is strictly concave inside the interval $q \in[(1-h-a) t,(1-h+a) t]$ if $2 m<1+2 \lambda$, which also holds if $\pi \lambda>m$. Hence, if the cost of auditing is not excessive (i.e., $\pi \lambda>m$ ), the optimal auditing probability is unique and is either determined by $\frac{\partial W(q)}{\partial q}=0$ for some $q \in((1-h-a) t,(1-h+a) t) \cap$ $[0,1]$, which yields

$$
q^{*}=t\left(1+\frac{\pi(m a+h m-h \lambda+a \lambda+m)-2 m a}{\pi(1-2 m+2 \lambda)}\right)
$$

or a corner solution with $q=\min \{(1-h+a) t, 1\}$. This result can be used to study the comparative static properties of this equilibrium. 
Proposition 2 Let $\pi \lambda>m$. (i) In an equilibrium with an interior auditing probability $q(h)$, the probability that the citizen with $y=1$ reports truthfully is

$$
\phi(h, a) \equiv \frac{1}{2} \frac{\pi h-\pi h m+\pi h \lambda+\pi a-m a \pi+3 \pi a \lambda+\pi m-2 m a}{a \pi(1-2 m+2 \lambda)} .
$$

This share $\phi(h, a)$ is increasing in the expected patriotism $h$ and decreasing in the dispersion a of patriotism. (ii) If the optimal auditing probability is a corner solution with $q(h)=(1-h+a) t$, then a small increase in $h$ decreases the optimal auditing probability and leaves full compliance unaffected.

Proof. Consider first (i) The reporting behavior of the citizen for different incomes as a function of the auditing probability in stage 2 has been derived already. The government maximizes (8) by its choice of $q$. Recall that $W(q)$ as in (8) is concave for $\pi \lambda>m$. Rewriting the first-order condition characterizing an interior equilibrium yields

$$
q(h)=t \frac{-2 m a+m a \pi+\pi-\pi m+2 \pi \lambda-\pi h \lambda+\pi a \lambda+\pi h m}{\pi(1-2 m+2 \lambda)} .
$$

The choice of $q$ in (10) determines the critical value of $\eta_{0}$ in the equilibrium as a function of $h$ :

$$
\eta_{0}(h)=-\frac{\pi m-2 m a+m a \pi-\pi h \lambda+\pi a \lambda+\pi h m}{\pi(1-2 m+2 \lambda)} .
$$

In turn, this critical value determines the probability that $\eta>\eta_{0}(h)$ as

$$
\begin{aligned}
\phi(h, a) & \equiv\left(h+a-\eta_{0}(h)\right) \frac{1}{2 a} \\
& =\frac{1}{2} \frac{\pi h-\pi h m+\pi h \lambda+\pi a-m a \pi+3 \pi a \lambda+\pi m-2 m a}{a \pi(1-2 m+2 \lambda) .}
\end{aligned}
$$

This probability can be used for comparative statics with respect to $h$ and $a$. We find

$$
\frac{\partial \phi(h, a)}{\partial h}=\frac{1}{2} \frac{1-m+\lambda}{a(1-2 m+2 \lambda)}
$$

and

$$
\frac{\partial \phi(h, a)}{\partial a}=-\frac{1}{2} \frac{m+h \lambda-h m+h}{a^{2}(1-2 m+2 \lambda)} .
$$

Recall that a citizen with $y=0$ reports truthfully, irrespective of her $\eta$. Accordingly, for $\pi \lambda>m$, starting from an interior equilibrium, the share of citizen types who report truthfully is $(1-\pi)+\pi \phi(h, a)$, and is increasing in $h$ and decreasing in $a$.

Consider part (ii) of the proposition. If the solution is a corner solution with $q=(1-h-a) t$ for all citizen types, then a small further increase in $h$ does not move the equilibrium away from the corner solution. It decreases $q$, but full compliance continues to hold. 
This result provides the main hypothesis for our empirical analysis:

Hypothesis: (i) There is a positive relationship between patriotism and tax compliance on the individual level (for individuals' differences in actual $\eta$ ) and

(ii) on the country level (for differences in expected $\eta$ between different countries).

On the individual level, the hypothesis simply follows from the existence of a threshold level of $\eta$ in (11). An individual with high income is more likely to report truthfully if $\eta$ is high than if $\eta$ is low. The theoretical prediction is very sharp, suggesting that there is a threshold level of $\eta$ above which individuals comply and below which they do not. Of course, in the data other random factors play a role. Further, on the country level, Proposition 2 suggests that countries with higher mean patriotism $h$ should have less tax evasion. The connection is less straightforward. A higher average patriotism and the higher tax compliance change the composition of the citizens who report that their income is low. The share of citizens whose income is truly low becomes higher, as their absolute number is unchanged but the absolute number of citizens who have high income but report low income becomes smaller. In this environment auditing is less effective, as each audit has a given cost, but the share of audits which detect tax evasion is reduced. As a result the government may also reduce its auditing intensity. This, in turn, increases the threshold level of patriotism that induces truthful tax compliance, and in turn, increases the share of citizens who have high income but report low income. This is a countervailing effect. But as shown in Proposition 2, this indirect countervailing effect cannot overcompensate the direct effect.

\section{Data}

\subsection{Individual level}

As individualized data on participation in the shadow economy do not exist, we proxy individuals' tax compliance with their judgments on whether tax evasion is a legitimate activity. More precisely, we draw on a question in the "Citizenship 2004" module of the International Social Survey Programme (ISSP). The central question is:

There are different opinions as to what it takes to be a good citizen. As far as you are concerned personally on a scale of 1 to 7 , where 1 is not at all important and 7 is very important, how important is it: Never to try to evade taxes.

This variable closely resembles a corresponding question in the World Values Survey, which is across countries associated with measures of the size of the shadow economy (see Torgler and Schneider 2007, 2008, Slemrod 2007 and references therein). Moreover, Torgler (2004a) reports a high correlation between such a question and tax compliance in lab experiments. Hence, we think that this indirect measure of tax compliance is a good proxy of actual behavior. 
The main explanatory variable is patriotism, which is generated from a set of questions in the "National Identity 2003" module regarding the respondent's pride, "How proud are you of [country] in each of the following?", where [country] is the respondent's country of residence. ${ }^{12}$ Although this module provides information for more than 20 countries we can use only a subset of the data. In the majority of countries participating in the ISSP the two modules on national identity and citizenship are separate studies. However, eight countries conducted the two studies jointly ${ }^{13}$ and asked the same persons both sets of questions. Our dataset comprises those persons' answers who took part in both surveys. The sample size varies between 911 and 1,704 observations per country resulting in 9,973 observations for the whole dataset. ${ }^{14}$

The pride question is asked for ten different economic, historical and political characteristics of the country (see Table 1). They are asked as a set of questions in one

Table 1: Factor analysis

\begin{tabular}{l|l}
\hline & Factor loadings \\
\hline the way democracy works & .60333416 \\
country's economic achievements & .69783102 \\
its scientific and technological achievements & .68078557 \\
its fair and equal treatment of all groups & .60224421 \\
its achievements in the arts and literature & .53333066 \\
its history & .48520555 \\
its political influence in the world & .59697437 \\
its achievements in sports & .45590345 \\
country's armed forces & .5618465 \\
\hline Number of observations: 7210 & \\
\hline \hline
\end{tabular}

subsection of the questionnaire, thereby indicating that they refer to the same topic. For all ten questions the respondents are asked to answer on the same four-point scale ranging from "very proud" to "not proud at all". We drop the question on pride in the social security system, since it may be closely linked to tax compliance. A factor analysis of the remaining nine questions reveals that they are indeed linked to a single underlying concept. There is only one factor with an eigenvalue larger than unity and hence we employ the predicted score of this factor as our measure of patriotism. ${ }^{15} \mathrm{~A}$

\footnotetext{
${ }^{12}$ Since some of the questions ask the respondent about the opinion on "her" country, it is not clear to which country the non-national respondent actually refers. Therefore, we exclude the small number of non-nationals from our sample.

${ }^{13}$ The eight countries are USA, Austria, Ireland, Netherlands, Poland, Canada, Portugal, Uruguay.

${ }^{14}$ The total number of persons in the dataset is 9,973 . Due to missing values the number of observations in the following regressions is roughly between 5,400 and 7,800 , depending on the set of control variables.

${ }^{15}$ This method is also applied in Qari, Konrad and Geys (2008), who provide a theoretical and empirical assessment of the relationship between patriotism as a measure of home attachment in a framework with international mobility and the statutory tax rates. We also check alternative measures of patriotism which do not rely on factor analysis / principal component analysis.
} 
second standard approach to aggregate a number of correlated variables is principal component analysis. In our special case the two approaches are virtually identical, since patriotism constitutes the only underlying factor which explains most of the variation. The correlation coefficient between the first principal component and the first factor score is 0.9987 and confirms that the two approaches yield the same results.

The rationale to use these questions to measure patriotism is in line with previous research. For example, Huddy and Khatib (2007) analyze a similar set of questions of the General Social Survey. In their sample the questions on "democracy", "economic achievements", "fair and equal treatment" and "social security system" are highly correlated with latent "National Pride". The question on "political influence in the world" which turns out to be strongly correlated with patriotism in our sample was not part of their analysis. Another important implication of their study is the distinction between patriotism ("National Pride") and nationalism, which is captured by questions like "America is a better country than most others". ${ }^{16}$ In their factor analysis patriotism and nationalism emerged as two clearly distinct but weakly correlated underlying concepts. ${ }^{17}$ De Figueiredo and Elkins (2003) analyze the ISSP "National Identity 1995" study and find the same five questions to be highly correlated with patriotism.

\subsection{Country level}

A simple way to generate a measure of patriotism on the country level is to calculate the average factor score for each of the countries. To check whether our measure of patriotism reflects differences across nations we regress individual patriotism on a set of country dummies. Table 2 clearly indicates differences across the countries. Average patriotism is highest in the United States, followed by Ireland and Canada. Poland and Portugal are the least patriotic countries. ${ }^{18}$ More importantly, approximately $26 \%$ of the total patriotism variance can be attributed to the respondent's country of residence.

It would be desirable to use the same dataset for both parts of the analysis to check if the results from the individual analysis carry over to the country level. However, in this case we would be left with only eight observations on the country level which precludes any empirical analysis. Note that the country level analysis does not require those respondents' observations who participated in both the ISSP National Identity and Citizenship modules. Thus we now use all observations from the National Identity 2003 study for which the pride questions are non-missing and run a factor analysis on

\footnotetext{
${ }^{16}$ For recent studies on the relationship between nationalism and immigration see O'Rourke and Sinnott (2006) and Mayda (2006). Mayda and Rodrik (2005) show that nationalism is associated with protectionist tendencies. All three articles use the ISSP "National Identity 1995" module. The set of questions in the 1995 module is largely congruent with the 2003 module.

${ }^{17}$ See the references in Huddy and Khatib (2007) for the broad literature on the distinction between patriotism and nationalism. To check if our patriotism variable picks up nationalism, we have regressed a question capturing attitudes toward immigrants on our patriotism measure and a number of individual controls. This test clearly shows that more patriotic individuals hold positive views about immigrants.

${ }^{18}$ Note that the sign is not important and just reflects the (arbitrary) normalization to a zero mean.
} 
Table 2: Patriotism per country

\begin{tabular}{lrr}
\hline \hline & \multicolumn{2}{c}{$(1)$} \\
\hline USA & $0.799^{* * *}$ & $(31.66)$ \\
AUT & $0.105^{* *}$ & $(3.28)$ \\
IRL & $0.505^{* * *}$ & $(18.04)$ \\
NLD & $-0.219^{* * *}$ & $(-9.69)$ \\
POL & $-0.545^{* * *}$ & $(-20.41)$ \\
CAN & $0.363^{* * *}$ & $(13.74)$ \\
PRT & $-0.458^{* * *}$ & $(-19.98)$ \\
URY & $-0.348^{* * *}$ & $(-12.63)$ \\
\hline Observations & 7210 & \\
Adjusted $R^{2}$ & 0.264 & \\
\hline \hline
\end{tabular}

$t$ statistics in parentheses

${ }^{*} p<0.10,{ }^{* *} p<0.05,{ }^{* * *} p<0.01$

The table presents OLS regression results (robust standard errors). The table regresses individual patriotism on a set of country dummies, where patriotism is the score for the first principal factor derived from a set of 9 pride questions.

this sample. As before (in the subsample of eight countries) only one strong factor emerges and we employ the factor score to measure an individual's patriotism. We then calculate the average patriotism for each country in the sample. We perform the same steps for the National Identity 1995 study and arrive at an unbalanced panel on the country level with two periods and 53 observations.

The second key variable on the country level is the size of the shadow economy. Schneider (2005) provides estimates for the extent of the shadow economy for the year 1995, while Schneider (2007) contains estimates for the year 2003. From these two sources we extract the 53 relevant values we need for the unbalanced country-level panel. There is no universally agreed definition of the shadow economy ${ }^{19}$ and the resulting estimate represents the size of the shadow economy as a fraction of the official GDP. Thus, it is not clear how this output gap is distributed along the various hidden sectors. But, as noted by Schneider and Enste (2000), almost all studies found that increasing tax and social security burdens are important determinants for the growing shadow economy. Hence, the size of the shadow economy should be highly correlated with tax evasion. ${ }^{20}$

\footnotetext{
${ }^{19}$ For an extensive discussion see Schneider and Enste (2000).

${ }^{20}$ The estimates provided by Schneider $(2005,2007)$ are obtained from a MIMIC (multiple indicator multiple cause) model. Jöreskog and Goldberger (1975) describe estimation procedure and properties of the resulting maximum likelihood estimator. For early applications of such a model to the hidden economy, see Frey and Weck-Hannemann (1984) and Giles (1999).
} 


\section{Patriotism and the size of the shadow economy}

We consider part (ii) of our hypothesis first, using the country data on patriotism and the shadow economy. It suggests a negative relationship between average patriotism and the size of the shadow economy. Given the small number of observations, we consider graphical evidence and simple correlation measures. The scatter-plot (Figure 1) shows the first results. It suggests a negative correlation between the size of the

Figure 1: Shadow economy and patriotism across countries, 2003

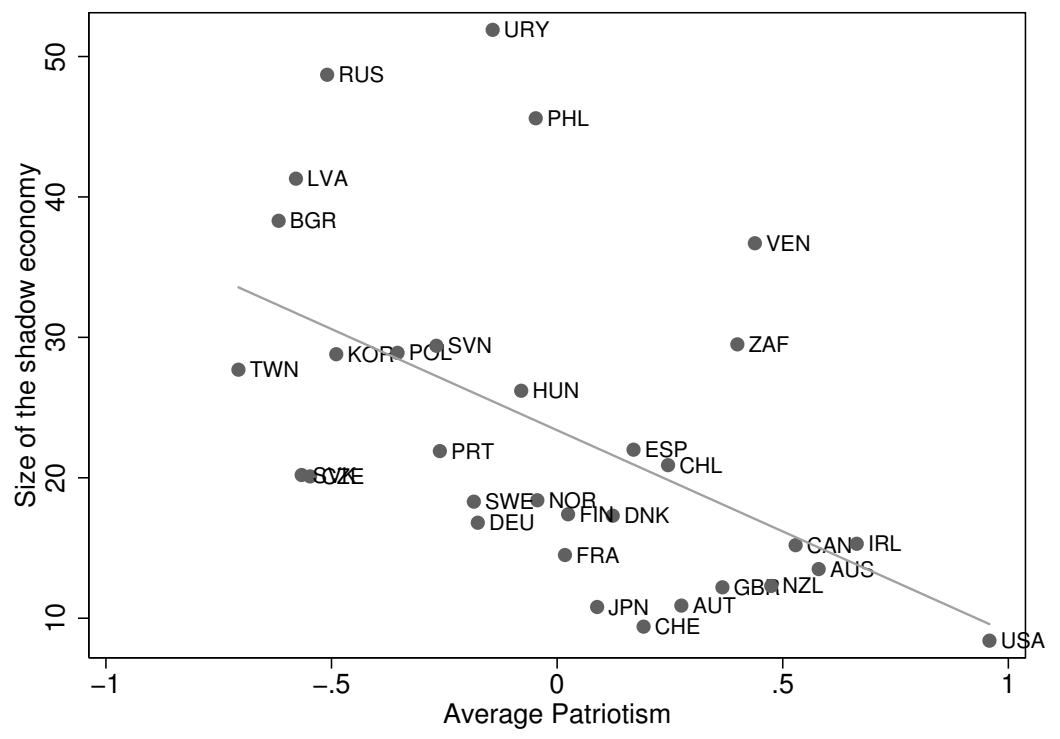

shadow economy and the average patriotic warm glow for the year 2003. The United States have the smallest hidden sector $(8.7 \%$ of the GDP) and constitute the most patriotic country in 2003.

Table 3 summarizes the results for the whole dataset. It regresses the size of the shadow economy on the average patriotic warm glow and presents the standardized (beta) coefficients. ${ }^{21}$ The first column uses patriotism as a single regressor, while column (2) additionally enters a dummy for the year 2003. Both regressions suggest that increasing patriotism by one standard deviation is associated with a decrease of the hidden sector by roughly $50 \%$ of its standard deviation. The second column additionally shows that the hidden economy in 2003 on average is slightly larger than in 1995.

The country level approach suffers from several drawbacks. Firstly, all variables are estimates itself with divergent levels of precision. For example, due to missing values there are less than 20 respondents available for particular countries in the sample. Moreover, the size of the shadow economy is modeled as a latent variable and relies

\footnotetext{
${ }^{21}$ The estimations are clearly subject to potential endogeneity problems and we therefore interpret the results as descriptive rather than causal.
} 
Table 3: Correlation between patriotism and the shadow economy

\begin{tabular}{lcc}
\hline \hline & $(1)$ & $(2)$ \\
\hline Aver. Proud & $-0.535^{* * *}$ & $-0.542^{* * *}$ \\
& $(-5.33)$ & $(-5.47)$ \\
Year 2003 & & 0.137 \\
& & $(1.23)$ \\
\hline$N$ & 53 & 53 \\
adj. $R^{2}$ & 0.272 & 0.277 \\
\hline \hline
\end{tabular}

Standardized beta coefficients; $t$ statistics in parentheses

${ }^{*} p<0.10,{ }^{* *} p<0.05,{ }^{* * *} p<0.01$

The table presents OLS regression results (robust standard errors). The explained variable is the size of the shadow economy (as a fraction of GDP). Aver. Proud is the average of individual patriotism, calculated separately for each country. Individual patriotism is the score for the first principal factor derived from a set of 9 pride questions. Year 2003 is a dummy for 2003.

on similar data sources as our measure of patriotism. Finally, it is not possible to disentangle the effects of patriotism and the different levels of law enforcement between the countries. Kaufmann (2006) provides indices of institutional quality and one of the six indicator is labeled "rule of law". But since these indices are as well treated as latent constructs and inferred from several hundred variables in 31 separate data sources (mostly survey data) they pick up similar variation as the patriotism measure. Due to these constraints we abstain from testing additional models and stick to the simple correlation measures. Nevertheless, the evidence supports our theoretical hypothesis.

\section{Patriotism and individual tax compliance}

We turn now to part (i) of the hypothesis and test the prediction that individual patriotism has a positive impact on individual's tax compliance. This part of the hypothesis is stronger than part (ii) on the country-level and the rich dataset allows us to consider several specifications. We run regressions of the following form:

$$
\text { Compliance }_{i, j}=\alpha_{j}+\beta_{1} \text { Proud }_{i, j}+\mathbf{x}_{\mathbf{i}, \mathbf{j}}^{\prime} \beta_{\mathbf{2}}+\epsilon_{i, j}
$$

Here Compliance $_{i, j}$ denotes tax compliance of individual $i$ in country $j$, Proud $_{i, j}$ denotes individual $i$ 's level of patriotism and $\mathbf{x}_{\mathbf{i}, \mathbf{j}}^{\prime}$ is a vector of individual-specific control variables which we will describe below. An important feature is the inclusion of country fixed effects, denoted by $\alpha_{j}$. Thus, our results are not driven by the different levels of institutional quality or enforcement in our sample of eight countries.

We firstly estimate equation (15) by OLS -thereby treating the response variable as 
interval data- and secondly by an ordered probit model. ${ }^{22}$ Our results indicate that both regression models yield very similar estimates. We mainly discuss the OLS results as the coefficients can be interpreted more straightforwardly.

To avoid that our patriotism variable reflects variation in other individual characteristics we use a series of individual level controls. For many of these controls there is no theoretical hypothesis for the direction of the effect. In the baseline estimations we consider only variables which should not involve any subjective judgment. These are age, sex, marital status, education, employment status, religion and type of work. This last variable asks if the respondent works for the government, a publicly owned firm, a private firm or whether she is self-employed. In a further step we include variables obtained from questions which involve a subjective rating, but might be important for the degree of tax compliance. These variables are church attendance, perceived corruption and social status. Except for age, all controls are entered as dummy variables. Our dataset provides ten categories for employment status and eleven categories for religious groups. In order to economize on the degrees of freedom given the sometimes sparse number of observations, we recode these. For employment status we keep "full-time", "part-time" and "retired", all others are coded into "other". For religion we keep the main groups "no religion", "roman catholic" and "protestant". Everything else is collapsed into "other".

Our hypothesis suggests a positive value for the coefficient $\beta_{1}$, which is equal to the marginal effect of patriotism on tax compliance if the model is fitted by OLS. For the ordered probit model $\beta_{1}$ is proportional to the marginal effect and a positive value implies that an increase in patriotism raises the probability of observing category seven of tax compliance and reduces the probability for category one.

Table 4 shows the baseline specification controlling for non-subjective individualspecific characteristics. The first and second column respectively show the OLS and ordered probit coefficients.

Starting the discussion of the results with the control variables, we confirm existing evidence for a strong gender effect. Females tend to report higher values of tax compliance, a finding in line with evidence from survey data (Torgler 2006) and experimental data (Alm 2007). Being married compared to being single increases tax compliance as well. ${ }^{23}$ Similar to the results in Slemrod (2007) and Andreoni, Erard and Feinstein (1998) we find that age positively affects compliance. Turning to education we find in both regressions some evidence for an inverse u-shape. Compliance is lowest for the reference group without any formal education and highest for the groups in the middle. The dummy for university degree is imprecisely estimated and slightly smaller as the coefficients for the education levels in the middle. Indicated by small coefficients and large standard errors, employment status is -at least in this sample-

\footnotetext{
${ }^{22}$ Estimation of fixed effects in nonlinear models can lead to biased and inconsistent estimates (incidental parameters problem). This is not an issue for our sample, since there are several hundred observations in each country. See, for example, Mayda (2006).

${ }^{23}$ Our results are in line with Torgler (2006). On the other hand, Slemrod (2007) and Andreoni, Erard and Feinstein (1998) report that married persons have higher rates of non-compliance.
} 
Table 4: Baseline regression results, OLS and ordered probit

\begin{tabular}{lcrrr}
\hline \hline & \multicolumn{2}{c}{ OLS } & \multicolumn{2}{c}{ Ordered probit } \\
\hline Proud & $0.241^{* * *}$ & $(10.02)$ & $0.219^{* * *}$ & $(10.58)$ \\
Female & $0.193^{* * *}$ & $(5.35)$ & $0.180^{* * *}$ & $(5.53)$ \\
Age & $0.00475^{* *}$ & $(2.90)$ & $0.00528^{* * *}$ & $(3.52)$ \\
Married & $0.102^{*}$ & $(2.04)$ & 0.0655 & $(1.58)$ \\
Widowed & -0.0757 & $(-0.89)$ & -0.0800 & $(-1.02)$ \\
Divorced & 0.0864 & $(1.13)$ & 0.0556 & $(0.83)$ \\
Separated & 0.0417 & $(0.33)$ & 0.0284 & $(0.24)$ \\
Lowest educ. & $0.256^{*}$ & $(1.97)$ & $0.209^{*}$ & $(2.05)$ \\
Above lowest educ. & $0.266^{*}$ & $(2.02)$ & $0.214^{*}$ & $(2.07)$ \\
Higher secondary educ. & $0.267^{*}$ & $(1.97)$ & $0.231^{*}$ & $(2.12)$ \\
Above higher secondary educ. & $0.254^{+}$ & $(1.88)$ & 0.162 & $(1.53)$ \\
University degree & 0.220 & $(1.62)$ & $0.179^{+}$ & $(1.66)$ \\
Part-time & 0.0346 & $(0.59)$ & -0.00417 & $(-0.08)$ \\
Retired & $0.0973^{+}$ & $(1.68)$ & 0.0616 & $(1.12)$ \\
Other & -0.0131 & $(-0.25)$ & -0.00917 & $(-0.20)$ \\
Public firm & -0.0203 & $(-0.30)$ & -0.0366 & $(-0.60)$ \\
Private firm & $-0.137^{* *}$ & $(-3.12)$ & $-0.131^{* *}$ & $(-3.17)$ \\
Self-employed & $-0.249^{* * *}$ & $(-4.30)$ & $-0.230^{* * *}$ & $(-4.48)$ \\
Catholic & $0.152^{* *}$ & $(2.69)$ & $0.112^{*}$ & $(2.52)$ \\
Protestant & $0.272^{* * *}$ & $(4.20)$ & $0.249^{* * *}$ & $(4.39)$ \\
Other & 0.00867 & $(0.08)$ & 0.00267 & $(0.03)$ \\
Country fixed effects & \multicolumn{3}{c}{ Yes } & \multicolumn{2}{c}{5963} \\
\hline Observations & \multicolumn{5}{c}{5963} & \\
\hline \hline
\end{tabular}

$t$ and $z$ statistics in parentheses, respectively

${ }^{*} p<0.10,{ }^{* *} p<0.05,{ }^{* * *} p<0.01$

The table presents OLS and ordered probit regression results (robust standard errors). The explained variable is individual tax compliance. The main explanatory variable is individual patriotism (Proud), which is the score for the first principal factor derived from a set of 9 pride questions. The regressions control for sex, age, marital status (reference category: singles), education (reference category: no formal education), employment status (reference category: full-time), work type (reference category: working for the government) and religious denomination (reference category: no religion). The table omits country-fixed effects, intercept and cut-off parameters. 
not an important factor for the degree of tax compliance. Workers in private firms and self-employed individuals have higher levels of non-compliance. Moreover, this negative impact is particularly strong for the self-employed. Catholics and protestants consider tax-compliance more important than the non-religious. The results indicate strong effects for both of these groups. The point estimate for protestants is larger than the coefficient for catholics.

We turn now to the main variable for testing our hypothesis. In both specifications the patriotism coefficient is fairly large and precisely estimated. The $t$ and $z$ ratio respectively is at least equal to ten in both estimations. For example, the OLS coefficient is equal to 0.241, suggesting that the increase in tax compliance associated with a marginal increase in patriotism is roughly as large as the decrease in tax compliance when being self-employed.

As already noted the ordered probit model yields similar results in the sense that the relative coefficient sizes resemble the OLS results. We also calculate the marginal effects for all seven categories of tax compliance, since they are not equivalent, but only proportional to the coefficients. Table 5 shows the results for the central patriotism

Table 5: Effects of marginal increase in patriotism

\begin{tabular}{lcccc}
\hline \hline & Prob(1) & Prob(2) & Prob(3) & \\
\hline Proud & -0.00728 & -0.00454 & -0.00788 & \\
& $(-8.13)$ & $(-6.88)$ & $(-8.22)$ & \\
\hline Prob(4) & Prob(5) & Prob(6) & Prob(7) \\
\hline Proud & -0.0234 & -0.0245 & -0.0193 & 0.0869 \\
& $(-9.65)$ & $(-9.72)$ & $(-9.47)$ & $(10.58)$ \\
\hline Observations & 5963 & & \\
\hline \hline Marginal effects; $z$ statistics in parentheses \\
This table uses the ordered probit results (Table 4, column (2)) and presents \\
the marginal effects of increasing patriotism, calculated for the seven tax \\
compliance categories.
\end{tabular}

variable. A marginal increment of patriotism increases the probability of the highest category of tax compliance approximately by eight percent. This increase stems from a corresponding decrease in the probability mass of all other categories. The decrease is stronger for categories four, five and six, thereby reflecting the fact that only a small fraction of individuals report levels of tax compliance below four. As in the OLS regression this marginal effect of patriotism is roughly as large as the discrete decrease in probability of category seven for self-employed persons. ${ }^{24}$

\footnotetext{
${ }^{24}$ The decrease for those individuals who are self-employed (rather than working for the government) is approximately equal to $10 \%$. It is calculated while holding the other regressors -including patriotismat their sample mean. As already discussed, beside patriotism and work type only sex and religious denomination are associated with large effects on tax compliance and discriminating power in our
} 
Finally, we predict the probability of belonging to the seven tax compliance categories for the entire range of patriotism holding the remaining regressors at the sample mean.

Figure 2: Probabilities of tax compliance

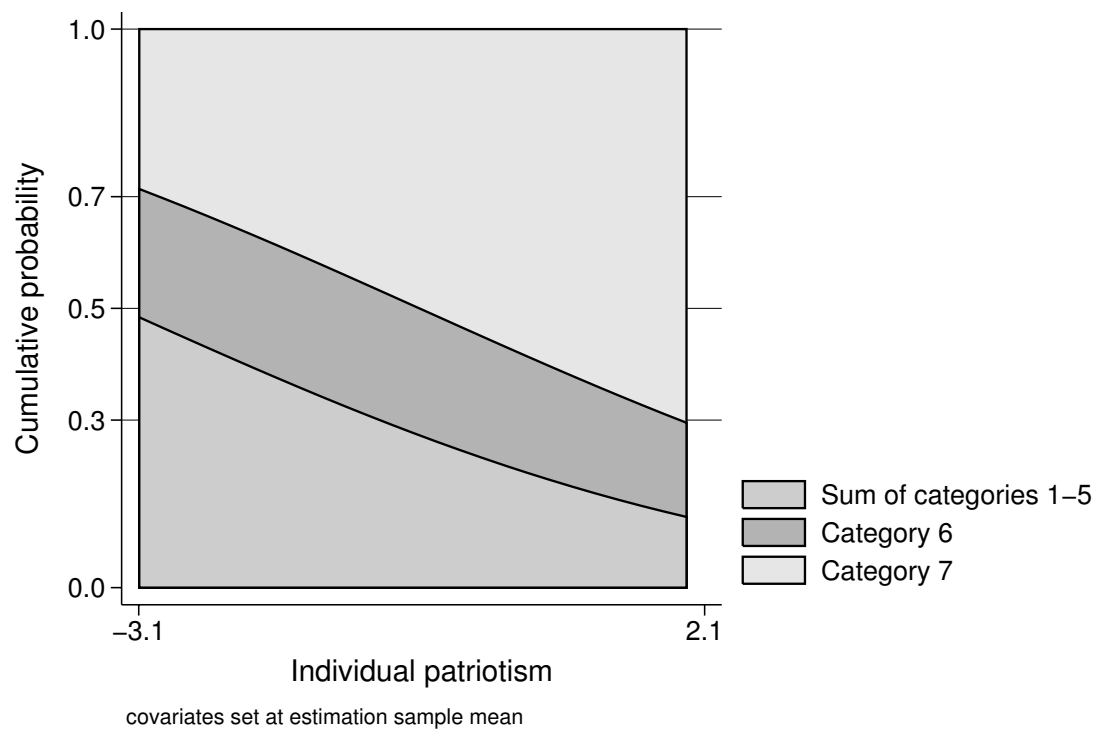

The figure uses the ordered probit results (see Table 4) to depict the probability of belonging to the seven tax compliance categories conditional on individual's patriotism. Categories 1-5 are collapsed to a single category because only a small fraction of individuals report tax compliance levels below four. The lower line represents the probability of reporting this collapsed category, while the upper line shows the cumulative probability of category six.

Figure 2 depicts the cumulative probabilities. The lower and upper line indicates the cumulative probability for the sum of categories 1-5 and category 6 , respectively. The most patriotic individuals report the highest level of tax compliance roughly with a probability of $70 \%$. For the least patriotic persons this probability is only about $30 \%$.

To summarize our results so far, we find evidence consistent with part (ii) of the theoretical predictions. More patriotic individuals are more tax compliant and this result emerges while controlling for a series of personal factors and unobserved country characteristics like the degree of law enforcement.

sample of ISSP respondents. The marginal effects for females, Catholics and Protestants are roughly $7 \%, 3 \%$ and $9 \%$, respectively. 


\section{Robustness checks}

\subsection{Income}

The baseline estimation controls for a number of important characteristics like type of work and employment status. But so far we have not included the respondent's income which affects the tax burden and therefore might influence compliance. Since income is given in local currency we standardize the variable to facilitate a meaningful comparison. We employ $\log \left(y_{i j} / \bar{y}_{j}\right)$ as normalized income, where $y_{i j}$ denotes the income of individual $i$ in country $j$ and $\bar{y}_{j}$ is the average income in country $j$ directly calculated from the sample. ${ }^{25}$ Hence, the resulting normalized income distribution is centered around zero for each of the countries. However, income has virtually no additional explanatory power (see Table A-1 in the supplementary appendix) and it does not affect the previous results. The income coefficient is small and insignificant.

\subsection{Extended set of controls}

The present subsection includes subjective variables as additional controls. Table 6 compiles the OLS regression results. The first column includes church attendance. The values for this variable are between one and eight, where one means that the individual attends church several times a week and eight means that she never goes to church. We derive three dummies from this variable: more than once a month (high), between once a month and once a year (middle), and less than once a year or never (low). High church attendance is the omitted reference group. The second column extends the model of the first column by introducing perceived corruption (Corruption). It is derived from the ISSP citizenship 2004 question on corruption, which reads "How widespread do you think corruption is in the public service in [country]?". It ranges from one, "hardly anyone is involved" to five, "almost everyone is involved". According to these groups five dummies are created, where lowest corruption acts as the reference category. Finally, the third column adds self-rated social class (Class) with possible answers ranging from one (lowest class) to ten. We create three groups: 1-4 (low), 5-7 (middle) and 8-10 (high). Low class is the reference category.

Table 6 firstly shows large estimates for church attendance (column 1) and corruption (column 2). However, the findings for corruption are limited by the fact that the coefficients for the different dummies are similar while only three percent of the individuals report that "hardly anyone" is involved in corruption. The large negative impact of less church attendance on tax compliance is robust across the three regressions. This finding is more meaningful as individuals in our sample sort themselves roughly uniformly into the three groups (high, middle and low). ${ }^{26}$

\footnotetext{
${ }^{25}$ Corneo and Grüner (2002) also apply this transformation to ISSP data.

${ }^{26}$ The strong positive effect of church attendance on tax compliance is reported by Torgler (2006) as well. He also considers a specification with interaction terms between different measures of "religiosity" and religious denominations, in which he finds a negative main effect for protestants, but a positive
} 
Table 6: OLS regression with extended set of controls

\begin{tabular}{|c|c|c|c|c|c|c|}
\hline & \multicolumn{2}{|c|}{ + + Attendance } & \multicolumn{2}{|c|}{+ Corruption } & \multicolumn{2}{|c|}{+ Social class } \\
\hline Proud & $0.238^{* * *}$ & $(9.71)$ & $0.238^{* * *}$ & $(9.46)$ & $0.242^{* * *}$ & $(9.36)$ \\
\hline Female & $0.178^{* * *}$ & $(4.84)$ & $0.167^{* * *}$ & $(4.46)$ & $0.155^{* * *}$ & $(4.06)$ \\
\hline Age & $0.00432^{* *}$ & $(2.61)$ & $0.00434^{* *}$ & $(2.60)$ & $0.00447^{* *}$ & $(2.63)$ \\
\hline Married & 0.0818 & $(1.62)$ & 0.0812 & $(1.57)$ & $0.0874^{+}$ & $(1.66)$ \\
\hline Widowed & -0.0981 & $(-1.14)$ & -0.0859 & $(-0.99)$ & -0.100 & $(-1.13)$ \\
\hline Divorced & 0.0807 & $(1.04)$ & 0.0855 & $(1.09)$ & 0.0550 & $(0.68)$ \\
\hline Separated & 0.0350 & $(0.28)$ & -0.000800 & $(-0.01)$ & 0.00153 & $(0.01)$ \\
\hline Lowest educ. & $0.246^{+}$ & $(1.87)$ & $0.282^{*}$ & $(2.05)$ & $0.266^{+}$ & $(1.91)$ \\
\hline Above lowest educ. & $0.273^{*}$ & $(2.05)$ & $0.295^{*}$ & $(2.12)$ & $0.267^{+}$ & $(1.88)$ \\
\hline Higher secondary educ. & $0.275^{*}$ & $(2.01)$ & $0.293^{*}$ & $(2.06)$ & $0.273^{+}$ & (1.87) \\
\hline Above higher secondary educ. & $0.254^{+}$ & $(1.86)$ & $0.278^{+}$ & $(1.95)$ & $0.266^{+}$ & $(1.82)$ \\
\hline University degree & 0.223 & $(1.62)$ & 0.235 & $(1.64)$ & 0.224 & $(1.51)$ \\
\hline Part-time & 0.0479 & $(0.82)$ & 0.0375 & $(0.62)$ & 0.0355 & $(0.58)$ \\
\hline Retired & $0.103^{+}$ & $(1.75)$ & $0.111^{+}$ & $(1.89)$ & $0.103^{+}$ & $(1.72)$ \\
\hline Other & 0.00740 & $(0.14)$ & 0.0156 & $(0.29)$ & 0.0116 & $(0.21)$ \\
\hline Public firm & -0.0379 & $(-0.56)$ & -0.0530 & $(-0.76)$ & -0.0537 & $(-0.76)$ \\
\hline Private firm & $-0.129^{* *}$ & $(-2.92)$ & $-0.131^{* *}$ & $(-2.92)$ & $-0.120^{* *}$ & $(-2.61)$ \\
\hline Self-employed & $-0.246^{* * *}$ & $(-4.19)$ & $-0.257^{* * *}$ & $(-4.30)$ & $-0.246^{* * *}$ & $(-4.07)$ \\
\hline Catholic & 0.0686 & $(1.02)$ & 0.0479 & $(0.71)$ & 0.0444 & $(0.64)$ \\
\hline Protestant & $0.161^{*}$ & $(2.25)$ & $0.156^{*}$ & $(2.16)$ & $0.148^{*}$ & $(2.00)$ \\
\hline Other & -0.0750 & $(-0.67)$ & -0.0745 & $(-0.65)$ & -0.0720 & $(-0.61)$ \\
\hline Attendance: middle & $-0.103^{*}$ & $(-2.44)$ & $-0.0890^{*}$ & $(-2.09)$ & $-0.0853^{*}$ & $(-1.96)$ \\
\hline Attendance: less and never & $-0.234^{* * *}$ & $(-4.62)$ & $-0.242^{* * *}$ & $(-4.67)$ & $-0.247^{* * *}$ & $(-4.64)$ \\
\hline Corruption $==2$ & & & $-0.209^{*}$ & $(-2.00)$ & $-0.194^{+}$ & $(-1.82)$ \\
\hline Corruption $==3$ & & & $-0.202^{+}$ & $(-1.91)$ & $-0.179^{+}$ & $(-1.65)$ \\
\hline Corruption $==4$ & & & $-0.218^{*}$ & $(-1.99)$ & $-0.202^{+}$ & $(-1.81)$ \\
\hline Corruption $==5$ & & & -0.189 & $(-1.46)$ & -0.170 & $(-1.30)$ \\
\hline Class: middle & & & & & -0.0131 & $(-0.28)$ \\
\hline Class: high & & & & & -0.108 & $(-1.60)$ \\
\hline Constant & $5.744^{* * *}$ & $(31.23)$ & $5.951^{* * *}$ & $(27.89)$ & $5.984^{* * *}$ & $(27.49)$ \\
\hline Country fixed effects & \multicolumn{2}{|c|}{ Yes } & \multicolumn{2}{|c|}{ Yes } & \multicolumn{2}{|c|}{ Yes } \\
\hline Observations & \multicolumn{2}{|c|}{5809} & \multicolumn{2}{|c|}{5605} & \multicolumn{2}{|c|}{5447} \\
\hline
\end{tabular}

$t$ statistics in parentheses

${ }^{*} p<0.10,{ }^{* *} p<0.05,{ }^{* * *} p<0.01$

The table presents OLS regression regression results (robust standard errors). It extends the baseline OLS regression (Table 4, column (1)). It sequentially adds church attendance (reference category: high), perceived corruption (reference category: lowest=1) and self-rated social class (reference category: low). See Table 4 for a description of the variables. 
The results for previously included controls are hardly affected. One exception are the coefficients for religious denomination which are roughly halved (the catholics coefficient thereby becomes statistically insignificant). The three regressions strongly corroborate the baseline results regarding patriotism. The coefficient is about 2.4 in the three estimations and $t$-ratios larger than nine are obtained. As in the previous section our results imply that the negative impact of being self-employed is approximately "compensated" by a one unit increase in patriotism. Thus, the three additional regressions confirm the strong effects of patriotism on tax compliance.

\subsection{Country-specific slopes}

We now check if our results are driven by pooling the eight country-specific subsamples into one single model. Table 7 introduces interaction terms between patriotism and the country dummies. The individual controls from the baseline estimation are included, but the coefficients are not shown to preserve space. The first two columns enter the country-specific slopes into the OLS and ordered probit model, respectively. The interaction terms show a positive effect of patriotism on tax compliance for each of the countries. The smallest slope is obtained for the United States. This is probably due to the fact that roughly $73 \%$ of the US citizens in our sample report the highest level of tax compliance. Since we include country fixed effects as well, there is not much variation left to exploit.

We employ usual Wald tests to test the null hypothesis of equal country slopes. For column 1 this hypothesis is rejected on conventional levels $(F(7,5927)=2.14, p=0.0364)$. Testing the same hypothesis for all slopes except the US slope (as well for column 1 ) we cannot reject the hypothesis $(F(6,5927)=1.48, p=0.1822)$. This is in line with the fact that there is less variation within the United States compared to the other countries. ${ }^{27}$

The main findings of this subsection are that all country-specific slopes are large and positive. Although there is some evidence for country-specific heterogeneity - especially the United States are seemingly singled out-, the empirical evidence of the baseline model emerges in the country-specific model as well. ${ }^{28}$

\subsection{Alternative patriotism measure}

The number of missing values for the nine pride questions is considerable and as a result a large amount of observations is lost. If individuals systematically refuse to

interaction effect which is larger than the main effect. However, we abstain from further exploration because it is not the focus of the present paper. Moreover, our dataset does not provide the same set of variables.

${ }^{27}$ However, when performing the same two tests for the ordered probit slopes (column 2) the null hypothesis has to be rejected in both cases $\left(\chi^{2}(7)=16.50, p=0.0210\right.$ and $\chi^{2}(6)=15.03, p=0.0201$, respectively). The test patterns for columns 3 and 4 resemble the findings from columns 1 and 2 .

${ }^{28} \mathrm{We}$ also introduced normalized income into the model with country-specific slopes. Columns 3 and 4 of Table 7 show the results. As in the baseline model, income has no additional explanatory power. 
Table 7: Introducing interaction terms (and income)

\begin{tabular}{lcccc}
\hline \hline & OLS & O. probit & OLS & O. probit \\
\hline USA x Proud & $0.106^{+}$ & $0.141^{*}$ & $0.114^{*}$ & $0.165^{*}$ \\
AUT x Proud & $(1.94)$ & $(2.17)$ & $(2.02)$ & $(2.45)$ \\
& $0.305^{* *}$ & $0.226^{* * *}$ & $0.244^{*}$ & $0.215^{* *}$ \\
IRL x Proud & $(3.20)$ & $(3.45)$ & $(2.36)$ & $(2.90)$ \\
& $0.433^{* * *}$ & $0.391^{* * *}$ & $0.489^{* * *}$ & $0.436^{* * *}$ \\
NLD x Proud & $(4.94)$ & $(5.37)$ & $(5.05)$ & $(5.49)$ \\
& $0.166^{*}$ & $0.0943^{*}$ & $0.161^{*}$ & $0.0888^{+}$ \\
POL x Proud & $(2.30)$ & $(1.99)$ & $(2.17)$ & $(1.83)$ \\
CAN x Proud & $0.359^{* * *}$ & $0.306^{* * *}$ & $0.359^{* * *}$ & $0.309^{* * *}$ \\
& $(4.55)$ & $(4.68)$ & $(4.36)$ & $(4.53)$ \\
PRT x Proud & $0.190^{*}$ & $0.249^{* *}$ & $0.229^{* *}$ & $0.279^{* * *}$ \\
& $(2.47)$ & $(3.20)$ & $(3.08)$ & $(3.62)$ \\
URY x Proud & $0.225^{* * *}$ & $0.211^{* * *}$ & $0.238^{* * *}$ & $0.232^{* * *}$ \\
& $(5.20)$ & $(5.04)$ & $(4.99)$ & $(4.92)$ \\
AUT & $0.246^{* * *}$ & $0.261^{* * *}$ & $0.266^{* * *}$ & $0.277^{* * *}$ \\
IRL & $(4.58)$ & $(4.92)$ & $(5.11)$ & $(5.31)$ \\
NLD & $-0.795^{* * *}$ & $-0.732^{* * *}$ & $-0.791^{* * *}$ & $-0.731^{* * *}$ \\
& $(-7.57)$ & $(-7.98)$ & $(-6.56)$ & $(-7.05)$ \\
POL & $-0.482^{* * *}$ & $-0.483^{* * *}$ & $-0.520^{* * *}$ & $-0.492^{* * *}$ \\
CAN & $(-4.53)$ & $(-5.06)$ & $(-4.38)$ & $(-4.73)$ \\
& $-0.771^{* * *}$ & $-0.757^{* * *}$ & $-0.795^{* * *}$ & $-0.768^{* * *}$ \\
PRT & $(-9.04)$ & $(-9.33)$ & $(-8.43)$ & $(-8.56)$ \\
URY & -0.0355 & -0.147 & -0.0428 & -0.139 \\
Income & $(-0.37)$ & $(-1.50)$ & $(-0.41)$ & $(-1.31)$ \\
Control variables & -0.128 & $-0.187^{*}$ & -0.149 & $-0.186^{+}$ \\
Observations & $(-1.41)$ & $(-2.01)$ & $(-1.53)$ & $(-1.88)$ \\
\hline \hline & -0.00732 & -0.135 & -0.0514 & -0.158 \\
& $(-0.09)$ & $(-1.54)$ & $(-0.53)$ & $(-1.60)$ \\
& 0.0511 & 0.0305 & 0.0237 & 0.0161 \\
& $(0.59)$ & $(0.33)$ & $(0.25)$ & $(0.16)$ \\
& & & 0.0215 & 0.0132 \\
& 5963 & 5963 & 5303 & 5303 \\
\hline
\end{tabular}

$t$ and $z$ statistics in parentheses, respectively.

${ }^{*} p<0.10,{ }^{* *} p<0.05,{ }^{* * *} p<0.01$

The table presents OLS and ordered probit regression results (robust standard errors). It extends the baseline estimation (Table 4) and introduces income as well different patriotism slopes for each country. The table only shows the estimated country-specific slopes and the country fixed effects (reference category: USA); the coefficients for the control variables and cut-off parameters are omitted. Individual patriotism (Proud) is the score for the first principal factor derived from a set of 9 pride questions. Income is respondent's reported total income. 
answer, our results may be driven by this selection process. We use the average of all non-missing pride questions as an alternative patriotism measure. The resulting score is between one and four for all respondents who provide at least one answer. Since Table A-2 (in the supplementary appendix) closely resembles our previous findings, we conclude that our results are not driven by systematic non-response. ${ }^{29}$

\subsection{Separate models for each country}

As a further step, we repeat the entire analysis separately for each country. We perform a series of principal component analyses on the eight subsamples to derive a countryspecific measure of patriotism. We then estimate the baseline model for each subsample. Table A-4 in the supplementary appendix shows the estimated effects for patriotism (not reporting the controls). Although there is considerable variation across the models, the coefficient is positive for each of the samples. As before, the smallest effect is found for the United States. Thus, our results are not driven by pooling the eight subsamples.

\subsection{Instrumental variables estimation}

As a final robustness check we instrument the patriotism variable. A literature in political psychology or political science in general (eg. Huddy 2001, Huddy and Khatib 2007) suggests that patriotism or in-group (own country) identification is correlated with higher levels of civic participation. Based on this argument we employ two indicator variables as instruments. One dummy is equal to one if the respondent took part in a demonstration in the past year and the second variable indicates if the respondent actively participates in a sports club. The instruments are relevant (F statistic on joint significance $F(2,5933)=11.16, p=0$, Stock-Wright $S$ statistic $\chi^{2}(1)=9.45$, $p=0.0089)$ and the null hypothesis of valid overidentifying restrictions is not rejected (Hansen $J$ statistic $\chi^{2}(1)=0.102, p=0.7497$ ).

Table 8 compiles the second stage results. If the IV coefficients for the control variables differed substantially from the previous OLS estimation, this would cast some doubts on the IV results. This is not an issue, since the IV and OLS results are qualitatively similar with the exception of the religious denomination coefficients, which are now smaller (the catholic coefficient is even negative) and statistically insignificant.

The coefficient for instrumented patriotism is equal to 1.2 and hence approximately five times larger than the OLS coefficient. This may be caused by a downward bias in the OLS estimation, if tax compliance has a negative impact on endogenous patriotism. ${ }^{30}$

\footnotetext{
${ }^{29}$ Note that the scale of the alternative patriotism measure is different. One might as well argue that the "fair and equal treatment of all groups" question refers to similar moral sentiments as tax compliance. Excluding the question yields very similar evidence (see Table A-3 in the supplementary appendix).

${ }^{30} \mathrm{~A}$ standard $C$ statistic rejects the orthogonality conditions for the patriotism variable and hence suggests that it is endogenous $\left(\chi^{2}(1)=6.159, p=0.0131\right)$.
} 
Table 8: 2SLS estimation (second stage)

\begin{tabular}{lcr}
\hline \hline & \multicolumn{2}{c}{$(1)$} \\
\hline Proud (instrumented) & $1.200^{* *}$ & $(2.69)$ \\
Female & $0.219^{* * *}$ & $(5.04)$ \\
Age & 0.00236 & $(1.09)$ \\
Married & 0.0283 & $(0.44)$ \\
Widowed & -0.175 & $(-1.62)$ \\
Divorced & 0.124 & $(1.38)$ \\
Separated & 0.151 & $(1.10)$ \\
Lowest educ. & $0.296^{*}$ & $(1.98)$ \\
Above lowest educ. & $0.320^{*}$ & $(2.10)$ \\
Higher secondary educ. & $0.349^{*}$ & $(2.19)$ \\
Above higher secondary educ. & $0.294^{+}$ & $(1.89)$ \\
University degree & $0.307^{+}$ & $(1.92)$ \\
Part-time & 0.0653 & $(0.94)$ \\
Retired & 0.107 & $(1.56)$ \\
Other & 0.0367 & $(0.58)$ \\
Public firm & 0.0405 & $(0.48)$ \\
Private firm & $-0.0975^{+}$ & $(-1.79)$ \\
Self-employed & $-0.227^{* * *}$ & $(-3.34)$ \\
Catholic & -0.165 & $(-1.03)$ \\
Protestant & 0.0201 & $(0.14)$ \\
Other & -0.110 & $(-0.82)$ \\
Constant & $5.011^{* * *}$ & $(15.55)$ \\
Country fixed effects & \multicolumn{2}{c}{ Yes } \\
\hline Observations & \multicolumn{2}{c}{5963} \\
\hline \hline
\end{tabular}

$t$ statistics in parentheses

${ }^{*} p<0.10,{ }^{* *} p<0.05,{ }^{* * *} p<0.01$

The table presents a 2SLS version of the baseline estimation (robust standard errors). See the baseline estimation (Table 4) for a description of the variables. 
If anything, this strengthens the baseline results, as it suggests that the impact of patriotism on tax compliance may actually be larger.

\section{Conclusions}

This paper explores the relationship between patriotism and tax compliance. Starting from existing observations according to which citizens may feel a warm glow of paying taxes, we have analyzed the relationship between optimal auditing and tax compliance if some citizens feel a patriotic warm glow of honestly declaring and paying their taxes. The hypotheses derived from this analysis are twofold. On the country level, tax compliance should be higher in countries with citizens who are more patriotic. On the individual level, tax compliance should be higher for those citizens who are more patriotic than others.

We test these two predictions using data from the International Social Survey Programme and find results that are fully in line with the theoretical predictions. Tax compliance and patriotism are positively correlated on the country level, and the same relationship holds on the individual level, controlling for a large number of socio-economic characteristics. We perform a variety of robustness checks to avoid spurious results. These checks include fitting country-specific patriotism slopes, using completely separated regressions for each country-subsample and finally an instrumental variable estimation to tackle the possible simultaneity between patriotism and tax compliance. While these tests cannot 'prove' our hypothesis, they provide strong empirical evidence supporting the hypothesis that patriotism is an important determinant for tax compliance.

These results are important, particularly because patriotism itself is endogenous and subject to governmental policy. The results suggest that revenue oriented governments may have an incentive to instrumentalize educational policy in order to instill patriotism, because patriotism may simplify tax collection: it may lead to higher compliance, even in an environment with less tax auditing. This effect of patriotism on tax compliance makes patriotism more desirable for a revenue oriented government. But, as discussed in the introduction, whether this is good news overall is rather a different matter. Patriotism has a number of undesirable side effects, particularly as it may turn into nationalism.

\section{References}

[1] Adams, Thomas F., 1911, Place of the income tax in the reform of state taxation, Bulletin of the American Economic Association, 4(2), 302-321

[2] Alm, James, and Sarah Jacobson, 2007, Using laboratory experiments in public economics, National Tax Journal, 60(1), 129-152. 
[3] Allingham, Michael G., and Agnar Sandmo, 1972, Income tax evasion, a theoretical analyis, Journal of Public Economics, 1(3-4), 323-338.

[4] Anderson, Frank F., 1917, Fundamental factors in war finance, Journal of Political Economy, 25(9), 857-887

[5] Andreoni, James, 1989, Giving with impure altruism - applications to charity and Ricardian equivalence, Journal of Political Economy, 97(6), 1447-1458.

[6] Andreoni, James, 1990, Impure altruism and donations to public goods - a theory of warm-glow giving, Economic Journal, 100(401), 464-477.

[7] Andreoni, James, Brian Erard, and Jonathan Feinstein, 1998, Tax compliance, Journal of Economic Literature, 36(2), 818-860.

[8] Bank, Steven A., Kirk J. Stark, and Joseph J. Thorndike, 2008, War and Taxes, UCLA School of Law, Research Paper No. 08-10, Urban Institute Press.

[9] Becker, Gary S., 1968, Crime and punishment: an economic approach, Journal of Political Economy, 76(2), 169-217.

[10] Ben-Porath, S., 2007, Civic virtue out of necessity, patriotism and democratic education, Theory and Research in Education, 5 (1), 41-59.

[11] Blumenthal, Marsha, Charles Christian, and Joel Slemrod, 2001, Taxpayer response to an increased probability of audit: evidence from a controlled experiment in Minnesota, Journal of Public Economics, 79(3), 455-483.

[12] Boadway, Robin, and Motohiro Sato, 2000, The optimality of punishing only the innocent: the case of tax evasion, International Tax and Public Finance, 7, 641-664.

[13] Brock, William A., and Steven N. Durlauf, 2001, Discrete choice with social interactions, Review of Economic Studies, 68, 235-260.

[14] Chander, Parkash, and Louis L. Wilde, 1998, A general characterization of optimal tax enforcement, Review of Economic Studies, 65(1), 165-183.

[15] Coricelli, Giorgio, Mateus Joffily, Claude Montmarquette, and Marie-Clare Villeval, 2007, The physionomics of tax evasion: cheating rationality or deciding emotionally? mimeo.

[16] Cremer, Helmuth, Maurice Marchand, and Pierre Pestieau, 1990, Evading, auditing and taxing, the equity-compliance tradeoff, Journal of Public Economics, 43, 67-92.

[17] Crumpler, Heidi, and Philip J. Grossman, 2008, An experimental test of warm glow giving, Journal of Public Economics, 92, 1011-1021. 
[18] de Figueiredo, Rui J.P., and Zachary Elkins, 2003, Are patriots bigots? An inquiry into the vices of in-group pride, American Journal of Political Science, 47(1), 171-188.

[19] Durand, E. Dana, 1917, Taxation versus bond issues for financing the war, Journal of Political Economy, 25(9), 888-916.

[20] Feldman, Naomi, and Joel Slemrod, 2006, War, social identity, and taxation: capitalizing patriotism through voluntary tax compliance, University of Michigan, mimeo.

[21] Fortin, Bernard, Guy Lacroix, and Marie-Claire Villeval, 2007, Tax evasion and social interactions, Journal of Public Economics, 91, 2089-2112.

[22] Frey, Bruno, 1997, A constitution for knaves crowds out civic virtues, Economic Journal, 107(443), 1043-53.

[23] Frey, Bruno S., and Benno Torgler, 2007, Tax morale and conditional cooperation, Journal of Comparative Economics, 35, 136-159.

[24] Frey, Bruno S., and Hannelore Weck-Hannemann, 1984, The hidden economy as an unobserved variable, European Economic Review, 26, 33-53.

[25] Giles, David E.A., 1999, Measuring the hidden economy: implications for econometric modelling, Economic Journal, 109, F370-F380.

[26] Gordon, James P.P., 1989, Individual morality and reputation costs as deterrents to tax evasion, European Economic Review, 33(4), 797-805

[27] Harbaugh, William T., Ulrich Mayr, and Daniel R. Burghart, 2007, Neural responses to taxation and voluntary giving reveal motives for charitable donations, Science, 316(5831), 1622-1625.

[28] Hill, Joseph. A., 1894, The Civil War income tax, Quarterly Journal of Economics, $8(4), 416-452$.

[29] Hartner, Martina, Silvia Rechberger, Erich Kirchler, and Alfred Schabmann, 2008, Procedural fairness and tax compliance, Economic Analysis \& Policy, 38(1), 137152.

[30] Huddy, Leonie, and Nadia Khatib, 2007, American patriotism, national identity, and political involvement, American Journal of Political Science, 51(1), 63-77.

[31] Jöreskog, Karl G., and Arthur S. Goldberger, 1975, Estimation of a model with multiple indicators and multiple causes of a single latent variable, Journal of the American Statistical Association, 70(351), 631-639. 
[32] Jones, Carolyn C., 1989, Class tax to mass tax: the role of propaganda in the expansion of the income tax during World War II, Buffalo Law Review, 37, 685-737.

[33] Jones, Carolyn C., 1996, Mass-based income taxation: Creating a tax paying culture, 1940-1952, in: W. Elliot Brownlee (ed.), Funding the modern American state, 1941-1995, The Rise and Fall of the Era of Easy Finance, Woodrow Wilson Center Press and Cambridge University Press, 107-147.

[34] Kaufmann, Daniel, Aart Kraay, and Massimo Mastruzzi, 2006, Governance matters V: aggregate and individual governance indicators for 1996-2005, Policy Research Working Paper Series 4012, The World Bank.

[35] Kennedy, Peter, 2005, A Guide to Econometrics (5th Edition), Maldon/Oxford UK: Blackwell Publishing.

[36] Konrad, Kai A., 2008, Mobile tax base as a global common, International Tax and Public Finance, 15(4), 395-414.

[37] Levi, Margaret, 1997, Consent, Dissent, and Patriotism, Cambridge, Cambridge University Press.

[38] Macho-Stadler, Ines, and J. David Perez-Castrillo, 1997, Optimal auditing with heterogenous income sources, International Economic Review, 38(4), 951-968.

[39] Maosen, L., 1990, Moral education in the People's Republic of China, Journal of Moral Education, 19 (3), 159-171.

[40] Mayda, Anna M., 2006, Who is against immigration? A cross-country investigation of individual attitudes toward immigrants, The Review of Economics and Statistics, $88(3), 510-530$.

[41] Mayda, Anna M., and Dani Rodrik, 2005, Why are some people (and countries) more protectionist than others?, European Economic Review, 49, 1393-1430.

[42] O'Rourke, Kevin H., and Richard Sinnott, 2006, The determinants of individual attitudes towards immigration, European Journal of Political Economy, 22, 838-861.

[43] Qari, Salmai, Kai A. Konrad, and Benny Geys, 2008, Patriotism, taxation and international migration, manuscript.

[44] Reinganum, Jennifer F., and Louis L. Wilde, 1985, Income tax compliance in a principal-agent framework, Journal of Public Economics, 26, 1-18

[45] Schneider, Friedrich, 2005, Shadow economies around the world: what do we really know?, European Journal of Political Economy, 21(3), 598-642. 
[46] Schneider, Friedrich, 2007, Shadow Economies and Corruption All Over the World: New Estimates for 145 Countries, Economics - The Open-Access, Open-Assessment E-Journal, 1(9).

[47] Schneider, Friedrich and Dominik H. Enste, 2000, Shadow economies: size, causes, and consequences, Journal of Economic Literature, 38,77-114.

[48] Slemrod, Joel, 2007, Cheating ourselves: the economics of tax evasion, Journal of Economic Perspectives, 21(1), 25-48.

[49] Torgler, Benno, 2004a, Cross-culture comparison of tax morale and tax compliance: evidence from Costa Rica and Switzerland, International Journal of Comparative Sociology, 45(1-2), 17-43

[50] Torgler, Benno, 2004b, Moral suasion: an alternative tax policy strategy? Evidence from a controlled field experiment, Economics of Governance, 5(3), 235-253.

[51] Torgler, Benno, 2006, The importance of faith: tax morale and religiosity, Journal of Economic Behavior \& Organization, 61, 81-109.

[52] Torgler, Benno, and Friedrich Schneider, 2007, Shadow economy, tax morale, governance and instituitional quality: a panel analysis, IZA discussion paper No. 2563.

[53] Torgler, Benno, and Friedrich Schneider, 2008, The impact of tax morale and institutional quality on the shadow economy, Journal of Economic Psychology, doi: 10.1016/j.joep.2008.08.004.

[54] Watts, Steven, 1995, Walt Disney: Art and Politics in the American Century, Journal of American History, 82 (1), 84-110. 


\section{Supplementary Appendix}

Proof of Proposition 1. Consider the government's choice of an audit policy in stage 1. Auditing a citizen who reports $\delta=1$ is never optimal ex ante, as it does not change the citizen's behavior and generates a cost of $-m$ if the audit takes place. Hence, the optimal audit probability for $\delta=1$ is zero.

Let $q$ be the audit probability for $\delta=1$ in what follows. For a given $(q, \theta)$ and the distribution of $\eta$, the probability that the citizen with income $y=1$ reports truthfully is

$$
P(q \theta)=\left\{\begin{array}{clc}
1 & \text { if } & q \theta>(1-h+a) t \\
\left.h+a-\left(1-\frac{q \theta}{t}\right)\right) \frac{1}{2 a} & \text { if } & q \theta \in[(1-h-a) t,(1-h+a) t] \\
0 & \text { if } & q \theta<(1-h-a) t
\end{array}\right.
$$

and, similarly, the probability that the citizen with income $y=1$ reports untruthfully is the complementary probability $(1-P(q \theta))$. Using these probabilities, and knowing the a-priori distribution of $y$ and $\eta$, the government can calculate aggregate welfare as a function of $(q, \theta)$, taking (3) into account. This welfare is

$$
\begin{aligned}
W(q, \theta)= & -(1-\pi) q m \\
& +\pi P(q \theta)\left(1+\lambda t+E\left(\eta \mid \eta \geq 1-\frac{q \theta}{t}\right) t\right) \\
& +\pi(1-P(q \theta))(q(1-m+\lambda \theta)+(1-q)) .
\end{aligned}
$$

Equation (A-2) can be transformed into

$$
\begin{aligned}
W(q, \theta)= & -(1-\pi) q m-\pi(1-P(q \theta)) q m \\
& +\pi P(q \theta)\left(1+\lambda t+E\left(\eta \mid \eta \geq 1-\frac{q \theta}{t}\right) t\right) \\
& +\pi(1-P(q \theta))(1+q \lambda \theta)
\end{aligned}
$$

Note that the expressions in the second and third line of (A-3) are functions of the product $q \theta$ only. Note further that, for any given $q \theta=\Theta$, the first line in (A-3) is maximized by choosing $q$ as small as possible, i.e., by choosing $\theta$ as large as possible But $\max \{\theta\}=1$. This shows that the standard result on maximum punishment (Becker 1968) applies. 
Table A-1: Introducing income

\begin{tabular}{|c|c|c|c|c|}
\hline & \multicolumn{2}{|c|}{ OLS } & \multicolumn{2}{|c|}{ Ordered probit } \\
\hline Proud & $0.247^{* * *}$ & $(9.84)$ & $0.231^{* * *}$ & $(10.54)$ \\
\hline Female & $0.197^{* * *}$ & $(5.09)$ & $0.187^{* * *}$ & $(5.35)$ \\
\hline Age & $0.00498^{* *}$ & $(2.88)$ & $0.00531^{* * *}$ & * $(3.35)$ \\
\hline Married & $0.0920^{+}$ & $(1.69)$ & 0.0598 & $(1.32)$ \\
\hline Widowed & -0.0879 & $(-0.98)$ & -0.0807 & $(-0.98)$ \\
\hline Divorced & 0.0652 & $(0.81)$ & 0.0429 & $(0.61)$ \\
\hline Separated & -0.0219 & $(-0.17)$ & -0.0336 & $(-0.27)$ \\
\hline Lowest educ. & $0.254^{+}$ & $(1.84)$ & $0.199^{+}$ & $(1.82)$ \\
\hline Above lowest educ. & $0.232^{+}$ & $(1.65)$ & 0.182 & $(1.64)$ \\
\hline Higher secondary educ. & $0.239^{+}$ & $(1.66)$ & 0.190 & $(1.63)$ \\
\hline Above higher secondary educ. & 0.231 & $(1.60)$ & 0.133 & $(1.16)$ \\
\hline University degree & 0.185 & $(1.25)$ & 0.134 & $(1.13)$ \\
\hline Part-time & 0.0250 & $(0.41)$ & -0.0116 & $(-0.21)$ \\
\hline Retired & $0.107^{+}$ & $(1.72)$ & 0.0634 & $(1.07)$ \\
\hline Other & -0.0146 & $(-0.26)$ & -0.0189 & $(-0.39)$ \\
\hline Public firm & -0.00432 & $(-0.06)$ & -0.0185 & $(-0.29)$ \\
\hline Private firm & $-0.0940^{*}$ & $(-2.03)$ & $-0.0929^{*}$ & $(-2.13)$ \\
\hline Self-employed & $-0.243^{* * *}$ & $(-3.91)$ & $-0.222^{* * *}$ & $(-4.05)$ \\
\hline Catholic & $0.111^{+}$ & $(1.88)$ & $0.0792^{+}$ & $(1.69)$ \\
\hline Protestant & $0.249^{* * *}$ & $(3.70)$ & $0.231^{* * *}$ & $(3.92)$ \\
\hline Other & 0.0369 & $(0.34)$ & 0.0192 & $(0.21)$ \\
\hline Income & 0.0165 & $(0.64)$ & 0.00996 & $(0.40)$ \\
\hline Country fixed effects & \multicolumn{2}{|c|}{ Yes } & \multicolumn{2}{|c|}{ Yes } \\
\hline Observations & \multicolumn{2}{|c|}{5303} & \multicolumn{2}{|c|}{5303} \\
\hline
\end{tabular}

$t$ and $z$ statistics in parentheses, respectively

${ }^{*} p<0.10,{ }^{* *} p<0.05,{ }^{* * *} p<0.01$

The table introduces (standardized) income into the baseline estimation. See the baseline estimation (Table 4) for a description of the variables. Country-fixed effects, intercept and cut-off parameters are not shown. 
Table A-2: Alternative patriotism measure: Average of non-missing answers

\begin{tabular}{|c|c|c|c|c|c|c|}
\hline \multirow[b]{2}{*}{ Proud 2} & \multicolumn{2}{|c|}{+ Attendance } & \multicolumn{2}{|c|}{+ Corruption } & \multicolumn{2}{|c|}{+ Social class } \\
\hline & $0.378^{* * *}$ & $(10.56)$ & $0.379^{* * *}$ & $(10.07)$ & $0.383^{* * *}$ & $(9.95)$ \\
\hline Female & $0.195^{* * *}$ & $(5.98)$ & $0.187^{* * *}$ & $(5.54)$ & $0.172^{* * *}$ & $(5.01)$ \\
\hline Age & $0.00596^{* * *}$ & $* \quad(4.10)$ & $0.00541^{* * *}$ & * $(3.66)$ & $0.00524^{* * *}$ & $*(3.47)$ \\
\hline Married & $0.0894^{*}$ & $(2.00)$ & $0.102^{*}$ & $(2.21)$ & $0.0980^{*}$ & $(2.09)$ \\
\hline Widowed & -0.0835 & $(-1.14)$ & -0.0645 & $(-0.85)$ & -0.0779 & $(-1.00)$ \\
\hline Divorced & 0.0757 & $(1.09)$ & 0.0988 & $(1.41)$ & 0.0745 & $(1.03)$ \\
\hline Separated & -0.00527 & $(-0.05)$ & -0.0202 & $(-0.18)$ & -0.0241 & $(-0.21)$ \\
\hline Lowest educ. & $0.196^{*}$ & $(2.03)$ & $0.213^{*}$ & $(2.01)$ & $0.214^{+}$ & $(1.94)$ \\
\hline Above lowest educ. & $0.228^{*}$ & $(2.29)$ & $0.227^{*}$ & $(2.09)$ & $0.212^{+}$ & $(1.88)$ \\
\hline Higher secondary educ. & $0.270^{* *}$ & $(2.60)$ & $0.255^{*}$ & $(2.28)$ & $0.243^{*}$ & $(2.07)$ \\
\hline Above higher secondary educ. & $0.204^{+}$ & $(1.95)$ & $0.208^{+}$ & $(1.84)$ & $0.205^{+}$ & $(1.73)$ \\
\hline University degree & $0.217^{*}$ & $(2.06)$ & $0.206^{+}$ & $(1.82)$ & $0.204^{+}$ & $(1.70)$ \\
\hline Part-time & 0.0671 & $(1.30)$ & 0.0730 & $(1.38)$ & 0.0715 & $(1.33)$ \\
\hline Retired & 0.0513 & $(1.00)$ & 0.0645 & $(1.24)$ & 0.0533 & $(1.00)$ \\
\hline Other & -0.00318 & $(-0.07)$ & 0.0168 & $(0.36)$ & 0.0184 & $(0.39)$ \\
\hline Public firm & -0.0608 & $(-1.00)$ & -0.0682 & $(-1.09)$ & -0.0740 & $(-1.16)$ \\
\hline Private firm & $-0.128^{* *}$ & $(-3.29)$ & $-0.135^{* * *}$ & $(-3.39)$ & $-0.127^{* *}$ & $(-3.12)$ \\
\hline Self-employed & $-0.240^{* * *}$ & $(-4.68)$ & $-0.260^{* * *}$ & $(-4.92)$ & $-0.260^{* * *}$ & $(-4.81)$ \\
\hline Catholic & 0.0348 & $(0.59)$ & 0.0158 & $(0.27)$ & 0.0130 & $(0.22)$ \\
\hline Protestant & $0.165^{* *}$ & $(2.61)$ & $0.166^{* *}$ & $(2.60)$ & $0.155^{*}$ & $(2.36)$ \\
\hline Other & -0.00441 & $(-0.05)$ & -0.0180 & $(-0.19)$ & 0.0125 & $(0.13)$ \\
\hline Attendance: middle & $-0.112^{* *}$ & $(-3.01)$ & $-0.0894^{*}$ & $(-2.34)$ & $-0.0929^{*}$ & $(-2.39)$ \\
\hline Attendance: less and never & $-0.225^{* * *}$ & $(-5.03)$ & $-0.223^{* * *}$ & $(-4.80)$ & $-0.239^{* * *}$ & $(-5.02)$ \\
\hline Corruption $==2$ & & & $-0.173^{+}$ & $(-1.83)$ & $-0.162^{+}$ & $(-1.66)$ \\
\hline Corruption $==3$ & & & $-0.188^{+}$ & $(-1.95)$ & $-0.169^{+}$ & $(-1.70)$ \\
\hline Corruption $==4$ & & & $-0.275^{* *}$ & $(-2.75)$ & $-0.259^{*}$ & $(-2.52)$ \\
\hline Corruption $==5$ & & & $-0.269^{*}$ & $(-2.31)$ & $-0.224^{+}$ & $(-1.89)$ \\
\hline Class: middle & & & & & -0.0136 & $(-0.33)$ \\
\hline Class: high & & & & & -0.0864 & $(-1.44)$ \\
\hline Constant & $4.612^{* * *}$ & $(24.34)$ & $4.849^{* * *}$ & $(21.55)$ & $4.881^{* * *}$ & $(21.05)$ \\
\hline Country fixed effects & $\mathrm{Ye}$ & & Yes & es & Yes & es \\
\hline Observations & 778 & & 733 & 36 & 709 & \\
\hline
\end{tabular}

$t$ statistics in parentheses

${ }^{*} p<0.10,{ }^{* *} p<0.05,{ }^{* * *} p<0.01$

The table presents OLS regression regression results (robust standard errors). Proud 2 is individual patriotism, calculated as the average of at most nine pride questions. See Table 4 and 6 for a description of the control variables. 
Table A-3: Alternative patriotism measure: Average of non-missing answers (set of eight questions)

\begin{tabular}{|c|c|c|c|c|c|c|}
\hline \multirow[b]{2}{*}{ Proud 3} & \multicolumn{2}{|c|}{ +Attendance } & \multicolumn{2}{|c|}{ +Corruption } & \multicolumn{2}{|c|}{ +Social class } \\
\hline & $0.368^{* * *}$ & $(10.34)$ & $0.365^{* * *}$ & $(9.75)$ & $0.369^{* * *}$ & $(9.64)$ \\
\hline Female & $0.188^{* * *}$ & $(5.77)$ & $0.180^{* * *}$ & $(5.35)$ & $0.166^{* * *}$ & $(4.82)$ \\
\hline Age & $0.00581^{* * *}$ & $* \quad(4.00)$ & $0.00528^{* * *}$ & * $(3.57)$ & $0.00511^{* * *}$ & * $(3.39)$ \\
\hline Married & $0.0860^{+}$ & $(1.92)$ & $0.0978^{*}$ & $(2.12)$ & $0.0935^{*}$ & (1.99) \\
\hline Widowed & -0.0853 & $(-1.16)$ & -0.0673 & $(-0.88)$ & -0.0802 & $(-1.02)$ \\
\hline Divorced & 0.0704 & $(1.02)$ & 0.0925 & $(1.32)$ & 0.0683 & $(0.95)$ \\
\hline Separated & -0.00819 & $(-0.08)$ & -0.0245 & $(-0.22)$ & -0.0286 & $(-0.25)$ \\
\hline Lowest educ. & $0.195^{*}$ & $(2.01)$ & $0.213^{*}$ & $(2.01)$ & $0.214^{+}$ & $(1.94)$ \\
\hline Above lowest educ. & $0.223^{*}$ & $(2.24)$ & $0.223^{*}$ & $(2.05)$ & $0.208^{+}$ & $(1.83)$ \\
\hline Higher secondary educ. & $0.266^{*}$ & $(2.56)$ & $0.252^{*}$ & $(2.25)$ & $0.238^{*}$ & $(2.03)$ \\
\hline Above higher secondary educ. & $0.201^{+}$ & $(1.92)$ & $0.205^{+}$ & $(1.81)$ & $0.201^{+}$ & $(1.69)$ \\
\hline University degree & $0.216^{*}$ & $(2.05)$ & $0.205^{+}$ & $(1.81)$ & $0.201^{+}$ & $(1.67)$ \\
\hline Part-time & 0.0690 & $(1.33)$ & 0.0743 & $(1.40)$ & 0.0727 & $(1.35)$ \\
\hline Retired & 0.0535 & $(1.04)$ & 0.0662 & $(1.28)$ & 0.0547 & $(1.03)$ \\
\hline Other & -0.00234 & $(-0.05)$ & 0.0185 & $(0.40)$ & 0.0208 & $(0.44)$ \\
\hline Public firm & -0.0543 & $(-0.89)$ & -0.0615 & $(-0.98)$ & -0.0668 & $(-1.05)$ \\
\hline Private firm & $-0.124^{* *}$ & $(-3.18)$ & $-0.130^{* *}$ & $(-3.27)$ & $-0.123^{* *}$ & $(-3.01)$ \\
\hline Self-employed & $-0.237^{* * *}$ & $(-4.63)$ & $-0.257^{* * *}$ & $(-4.86)$ & $-0.257^{* * *}$ & $(-4.76)$ \\
\hline Catholic & 0.0376 & $(0.64)$ & 0.0199 & $(0.34)$ & 0.0178 & $(0.29)$ \\
\hline Protestant & $0.167^{* *}$ & $(2.65)$ & $0.170^{* *}$ & $(2.65)$ & $0.159^{*}$ & $(2.42)$ \\
\hline Other & -0.00746 & $(-0.08)$ & -0.0207 & $(-0.21)$ & 0.0108 & $(0.11)$ \\
\hline Attendance: middle & $-0.115^{* *}$ & $(-3.09)$ & $-0.0926^{*}$ & $(-2.42)$ & $-0.0960^{*}$ & $(-2.47)$ \\
\hline Attendance: less and never & $-0.227^{* * *}$ & $(-5.08)$ & $-0.225^{* * *}$ & $(-4.85)$ & $-0.240^{* * *}$ & $(-5.05)$ \\
\hline Corruption $==2$ & & & $-0.176^{+}$ & $(-1.85)$ & $-0.164^{+}$ & $(-1.67)$ \\
\hline Corruption $==3$ & & & $-0.199^{*}$ & $(-2.06)$ & $-0.179^{+}$ & $(-1.81)$ \\
\hline Corruption $==4$ & & & $-0.285^{* *}$ & $(-2.85)$ & $-0.269^{* *}$ & $(-2.61)$ \\
\hline Corruption $==5$ & & & $-0.284^{*}$ & $(-2.44)$ & $-0.239^{*}$ & $(-2.02)$ \\
\hline Class: middle & & & & & -0.00820 & $(-0.20)$ \\
\hline Class: high & & & & & -0.0808 & $(-1.34)$ \\
\hline Constant & $4.639^{* * *}$ & $(24.49)$ & $4.896^{* * *}$ & $(21.77)$ & $4.925^{* * *}$ & $(21.24)$ \\
\hline Country fixed effects & Yes & es & Ye: & es & Ye: & es \\
\hline Observations & 778 & & 733 & 33 & 709 & 96 \\
\hline
\end{tabular}

$t$ statistics in parentheses

${ }^{*} p<0.10,{ }^{* *} p<0.05,{ }^{* * *} p<0.01$

The table presents OLS regression regression results (robust standard errors). Proud 3 is individual patriotism, calculated as the average of at most eight pride questions. See Table 4 and 6 for a description of the control variables. 


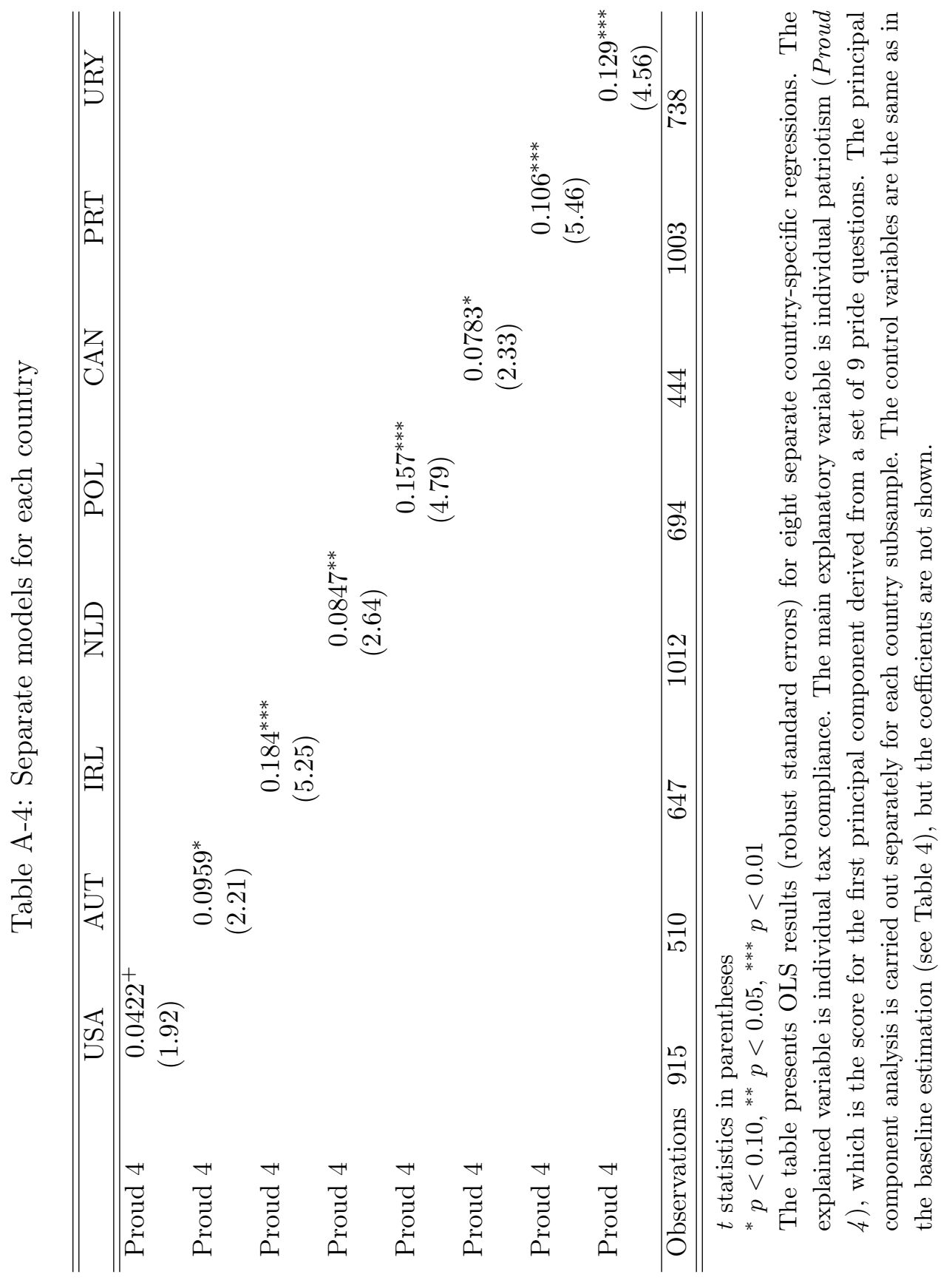

